\title{
Latest Therapies for Type 1 Diabetes: Exsisting Setup and "Post-Insulin" Standpoints
}

\author{
Ammira-Sarah Akil 1*, Aljazi Al-Maraghi, Esraa Yassin, Khulod Al-Malki, Khalid Fakhro \\ Precision Medicine Program, Human Genetics Department, Sidra Medicine, Doha, Qatar; \\ aalmaraghi@sidra.org, eyassin@sidra.org; kfakhro@sidra.org \\ *Correspondence: aakil@sidra.org ; Tel.: +974 40037406
}

\begin{abstract}
Type 1 diabetes affects millions of people globally and requires careful management to avoid serious long-term complications, including heart and kidney disease, stroke, and loss of sight. The present standard-of-care for type 1 diabetes is exogenic insulin substitutional therapy. The most advanced stretegies in this area is the development of hybrid-closed loop system and the producing of long-acting insulins. Progresses in stem cell therapies have started to revolutionize the care of patients with type 1 diabetes; however, significant challenges remain including the limited islets availability, difficulties in maintaining the viability, the heterogeneity within a complex pathology and in patients' responses to treatment. On the way, a considerable amount of efforts in maximizing the islet transplantation effectiveness by controlling the advantageous of different stem cell approaches. With the availability and the use of big data, the concept of precision medicine is gaining wide attention worldwide and could bring the dream of "presonlaized" therapies as a reality in the near future. Here we review the current range of treatments available as well as recent pre-clinical breakthroughs in the field of personlaized medicine for type 1 diabetes.
\end{abstract}

Keywords: Type 1 diabetes; insulin therapy; C-peptide; islet transplantation, mesenchymal stem cells; induced pluripotent stem cells; pancreatic $\beta$ cell; gene therapy; $\beta$-cell regeneration and reprogramming, type 1 diabetes precision medicine, diabetes personalized care.

\section{Introduction}

Type 1 Diabetes (T1D) is a devastating, multifactorial autoimmune disorder characterized by T-cell-mediated destruction of pancreatic $\beta$ cells, resulting in a deficiency of insulin synthesis and secretion [1]. The incidence of type 1 diabetes has been increasing globally 
since the 1950s, with an average annual increase of 3-4\% over the past three decades [2]. In particular, the incidence of childhood type 1 diabetes is increasing, most rapidly in populations that previously had a low incidence [3-5]. Worryingly, the disease incidence rate is larger than previously thought in this population and varies by ethnicity and race [4]. Most standardised long-term incidence data focus on children $<15$ years old: here, 1-3 children per 100,000 are affected per year in China and other Asian and South American countries, 10-20 per 100,000 in South European countries [2] and in the USA [6], and 30-60 per 100,000 in Scandinavia [2]. The risk of T1D increases with age, peaking around 10-14 years, but can occur at any age. Boys seem to be at a higher risk than girls in high-incidence countries, but the opposite pattern is seen in low-incidence countries [7].

Generally speaking, most countries have seen non-linear changes in T1D incidence over the long term, with periods of little or no increases such as in Norway from 2004 to 2012, in Finland from 2006 to 2011, and in the USA from 2002 to2012 [6].

The pancreas is the central organ involved in T1D pathogenesis. The healthy pancreas regulates macronutrient digestion and metabolic homeostasis via neuronally- and hormonally- regulated production of various digestive enzymes and pancreatic hormones [8]. Within the pancreas, pancreatic islets comprise a central core of insulin-producing $\beta$ cells surrounded by a-cells (which express glucagon), $\varepsilon$-cells (ghrelin), $\delta$-cells (somatostatin), and PP-cells (pancreatic polypeptide) [9]. When environmental factors such as infections [10], diet in early life [11], vitamin D levels [12], gut microbiota composition [13], vaccinations [14], pollutants and toxins [15], and geographic variation [16] combine with genetic susceptibility, autoimmune destruction of pancreatic $\beta$ cells is initiated, and T1D results [17] (Figure 1). Recent studies also show that the gut microbiota, enteroviruses and epigenetic modifications are involved in T1D pathogenesis [18-26]. 


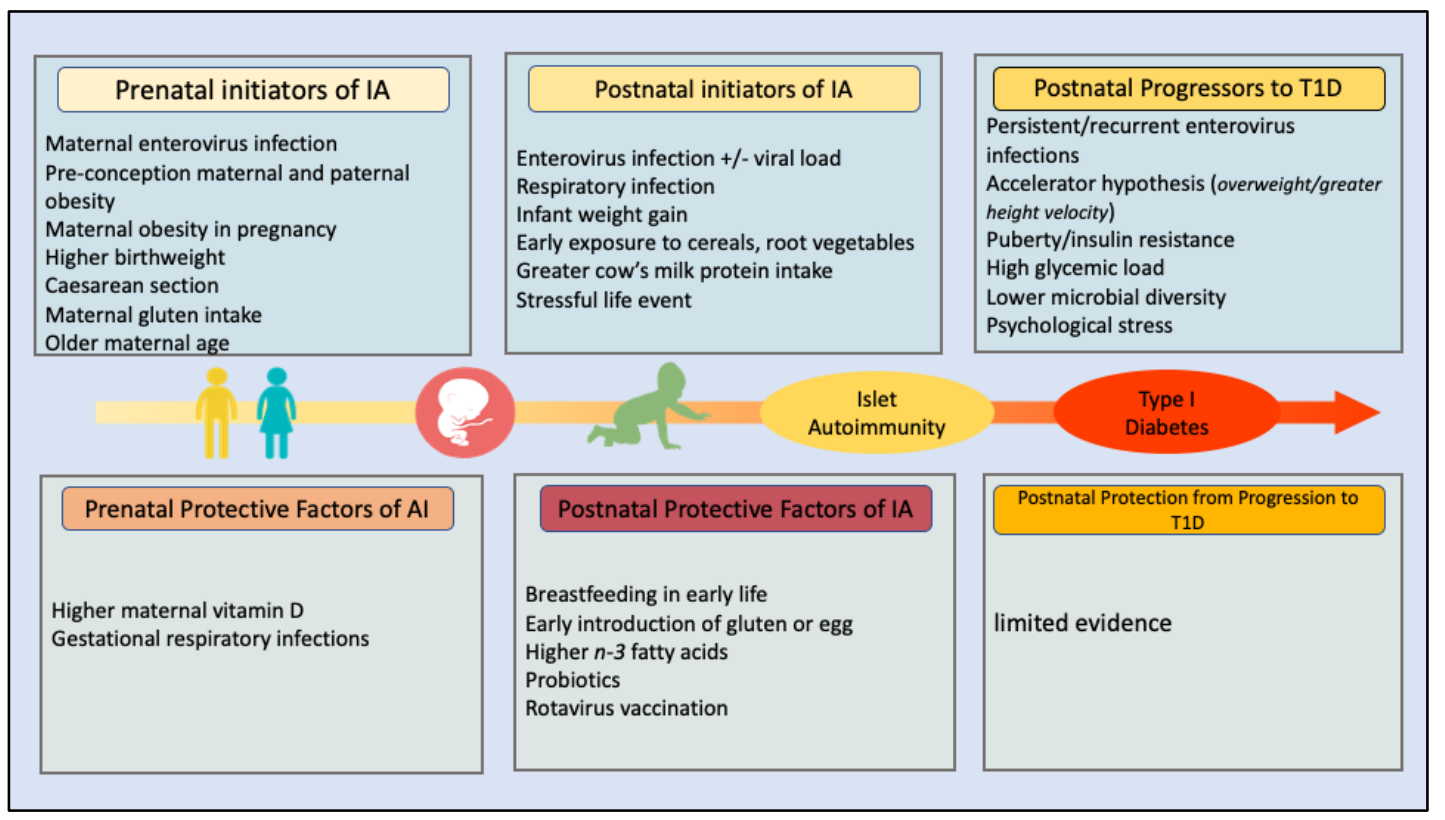

Figure 1: Environmental factors associated with initiation of, or protection from islet autoimmunity and progression to type 1 diabetes. Adopted from: Craig, M.E. et al., Diabetologia 62, 1823-1834 (2019). https://doi.org/10.1007/s00125-019-4942-x [27].

[27]

Despite these notable advances in understanding, there is no effective prevention or curative treatment for T1D. Achieving good glycemic control is necessary to prevent the long-term morbidity that is associated with poorly-controlled T1D; however the heterogeneity of factors initiating/ exacerbating the disease in individual patients, patients' diverse responses to these factors, and the variable efficacy of traditional therapies, render this simple aim complex to achieve in practice. An emerging move towards precision medicine may be the answer: precision medicine generates tailored diagnostic, prognostic, and therapeutic options for each patient based on their genetic background. By exploiting established clinical, phenotypic, physiological and pathological indexes this approach has the potential to provide the best available care for each patient, but is yet to be employed on a wide scale. In this review we summarize the current range of treatments available for T1D, as well as recent pre-clinical breakthroughs, and discuss how precision medicine might be implemented for the treatment of T1D in the future.

\section{Therapeutic Approaches}

Before the discovery of insulin in 1921, it was remarkable for T1D patients to live more than one or two years after disease onset: one of the twentieth century's utmost medical breakthroughs, insulin replacement, is still the only successful treatment for T1D patients today. That said, innovative ways of achieving improved insulin-mediated glycemic control are becoming accessible to patients, while tissue transplants, genetic modification and stemcell therapies are showing promise in pre-clinical models and human trials. 


\subsection{Insulin and Combination Drug Therapies}

The mainstay of traditional T1D treatment is manual testing of blood sugar levels followed by sub-cutaneous injections of insulin, repeated throughout the day. Insulin pumps may be used in place of traditional injections [28]]; these have the advantage of being able to continuously infuse small amounts of insulin sub-cutaneously, helping some patients achieve better control of their disease, especially when coupled with continuous glucose monitoring (CGM) technology. Since their first approval in 2016, CGM technologies have represented a significant step forward in insulin treatment, allowing the measurement of blood glucose levels in real-time and enabling patients to improve their control of blood glucose, thereby reducing long-term risks of diabetic complications[29, 30].

Taking the combination of CGM and continuous insulin infusion to the next level is the advent of the artificial pancreas. By utilizing a CGM coupled via a control algorithm to an implanted insulin pump, people with T1D can achieve improved glycemic outcomes while reducing the burden of self-management [31-33]. A closed-loop artificial pancreas approach removes the need for the patient to manage their dosages at all, and some models also incorporate the pancreatic hormone glucagon, enabling glucose-responsive hormone delivery guided by real-time glucose sensor readings. This approach has the potential to accommodate highly variable day-to-day insulin/glucagon requirements and can ensure tight glycemic control in affected patients $[34,35]$. Despite these advantages, still relatively few T1D sufferers are using an artificial pancreas approach, with the main obstacles being cost of the equipment, the need for a training infrastructure for users and clinicians, and a lack of clarity around which patient groups would benefit most from this technology (reviewed in [34].

Multidisciplinary approaches that combine nano-technologies with micro-technologies and tissue engineering are clearly advantageous in refining the therapeutic effectiveness of insulin. Here, a self-controlled drug-delivery profile as a function of glucose concentrations can be achieved, based on the activity of a glucose-sensing molecule and escalating drug stability[36-38]. In addition, the use of immunosuppressive drugs can be reduced, paving the way for long-term cell replacement therapy instead $[39,40]$.

Alongside developments in insulin replacement therapy, there has been a focus on identifying other drugs that can be combined with insulin to reduce hyper/hypoglycemia 
and improve metabolic variables without increasing adverse events (reviewed in [41]). Of these, promising candidates include metformin [42] and pramlintide, which have a role in glycemic control in both T1D and T2D and can modestly reduce triglyceride levels in T1D patients accompanied by HBA1c lowering and weight loss [43]. In addition, glucagon-like peptide-1 receptor agonists (GLP-RAs) combined with insulin can reduce the daily-weight required bolus insulin dose and improve glucose control and weight loss [44]. Dipeptidyl peptidase-4 inhibitors (DPP-4) are an adjunct therapy in a closed loop-system that can reduce postprandial blood glucose levels [45] and can significantly reduce the daily insulin dose but not the HBA1c level or the risk of hypoglycemia [46]. Finally, sodium-glucose cotransporter inhibitors (SGLTi) are associated with improved glycemic control and a reduced insulin dosage leading to lower rate of hypoglycemic episodes [47].

In summary, traditional and combined approaches to insulin therapy remain important tools in the treatment of T1D, but they do not represent a cure and may not be able to achieve the level of glucose control necessary to avoid long-term complications arising from diabetes. Thus increasing efforts are being made towards uncovering novel ways of restoring physiological regulation of glucose metabolism.

\subsection{Gene Therapy}

Gene therapy offers a promising alternative to insulin injection for T1D treatment and may aim to prevent or delay onset of T1D, correct insulin deficiency, promote $\beta$-cell proliferation and survival, modulate the immune/inflammatory response or induce insulin secretion by non- $\beta$ cells (reviewed in [48]). Of particular interest is the induced overexpression of insulin-like growth factor 1 (IGF1), which regulates immune functions and enhances the survival and proliferation of $\beta$-cells. Non-obese diabetic (NOD) mice spontaneously develop diabetes from around 10 weeks-of-age; however when 4-week-old NOD mice underwent intra-ductal injection of an adeno-associated virus (AAV) encoding IGF1 to specifically transduce pancreatic cells, normoglycemia remained in $80 \%$ of these mice at week 28 [49]. Importantly, the same study also showed that treating NOD mice with the IGF1-encoding virus at 11 weeks-of-age, by which time significant $\beta$-cell destruction was evident, was able to re-establish lasting normoglycemia in $75 \%$ of mice [49]. Gene therapy can also be used to induce insulin production in non- $\beta$-cells. Initial studies conducted on genetically engineered intestinal $\mathrm{K}$ cells [50] and hepatocytes [51] showed that these cells were sensitive to glucose and could be induced to produce insulin. More recently, Jaen et al. demonstrated that a single injection of AAV encoding insulin and glucokinase genes into 
skeletal muscle of diabetic dogs was able to induce metabolic normalization and normoglycaemia lasting 8 years [52]. This study represents an important safety and efficacy step forwards for diabetes gene therapy, as although AAV vectors have been trialed in humans, their therapeutic use for gene transduction has yet to be tested clinically. There are concerns that transduced cells might be susceptible to recurring autoimmune attack, so enduring autoimmune protection must be demonstrated $[53,54]$. It is also possible that the viral vectors themselves might trigger an immune response that could worsen the disease condition [55], though Jaen et al. did not report any evidence of this in their study [52]. Modifications to the AAV vectors might hold some of the answers: in response to concerns that constitutive over-expression of insulin might risk hypo-glycaemia, one group has developed a Tet-Off regulatable AAV vector for insulin expression that was able to both induce the expression of human insulin in diabetic mice, and be reversibly switched off to reduce insulin levels [56]. Thus fine tuning of viral vectors combined with more long-term studies will be required to move towards vector-mediated reinstatement of insulin production in human patients.

In addition to induced insulin expression, several studies have looked at other targets implicated in T1D pathogenesis. For example, Klotho is an anti-aging gene that is expressed in pancreatic islets in mice [57] and humans [58]; a Klotho deficiency is linked with $\beta$-cell apoptosis, and reinstating its expression in mice under the control of a $\beta$-cell-specific promoter led to protection of $\beta$-cell function [57]. In human islet cells, treatment with the T1D drug gamma-aminobutyric acid in vitro significantly increased Klotho expression [59], indicating the possible clinical potential for this approach. Combining gene therapy with immune modulation may also be promising. When NOD mice were pre-treated with antiT-cell receptor $\beta$ chain monoclonal antibody followed by hepatic gene therapy with Neurogenin-3 (which determines islet lineage) and the islet growth factor betacellulin, the researchers observed sustained induction of insulin-producing cells in the liver that achieved enduring reversal of new-onset or overt diabetes [60].

Lastly, a novel approach to gene therapy for T1D involves targeting post-transcriptional modifications that give rise to pathogenic splice variants. Cytotoxic T-lymphocyteassociated antigen-4 (CTLA-4) is an immune-modulatory protein where expression of different forms has been linked to T1D susceptibility or resistance [61]. To modulate the immune response leading to T1D onset, Mourich et al, employed an antisense-targeted splice-switching approach to produce CTLA-4 splice forms in NOD mouse T-cells [62]. In 
this study, when the antisense approach was used to mask pre-mRNA splice recognition sites and redirect the splicing machinery to skip selected exons, induced over-expression of the protective ligand-independent form of CTLA-4 protected NOD mice from disease [62].

\subsection{Whole Pancreas and Pancreatic Islets Transplantation}

The ideal T1D treatment would restore a fully functioning pancreas to patients, and one way of achieving this is by transplantation of a whole donor pancreas or pancreatic islets. Presently, over 50,000 patients with diabetes have been transplanted in more than 200 centers worldwide [63], but this procedure is far from a panacea: despite major improvements in patient survival rate, pancreatic transplantation is a complicated and risky procedure that is accompanied by the need for lifelong immunosuppressive and antiinflammatory agents that increase the risk of infections and tumors [64].

To avoid the major risk of pancreatic transplant surgery, transplantation of human pancreatic islets isolated from cadaver and pig pancreases has been developed. Initial clinical trials with a T1D patient demonstrated some success, with external insulinindependence lasting for up to 1 month before rejection of the graft due to inadequate immunosuppression [65-67], [68], [69]. It was not until 2000 that sustained long-term insulin-independence was achieved via the Edmonton Protocol (Figure 2). The fundamental principle of this protocol is the use of up to three cadaveric donor pancreases per recipient, allowing the infusion of an adequate islet cell mass $(>9,000$ islet equivalents per $\mathrm{kg}$ of recipient body weight) in combination with an immunosuppressant cocktail to prevent rejection [70]. At the 5-year follow up, only 15\% of patients in the program had lost the graft, and $\sim 25 \%$ had required a second transplant within 2-3 years of the initial graft; overall the procedure had been a success, achieving comparable survival rates to whole pancreas transplants without needing major surgery, and with almost half of patients reducing the amount of external insulin needed to control their disease [71]. 


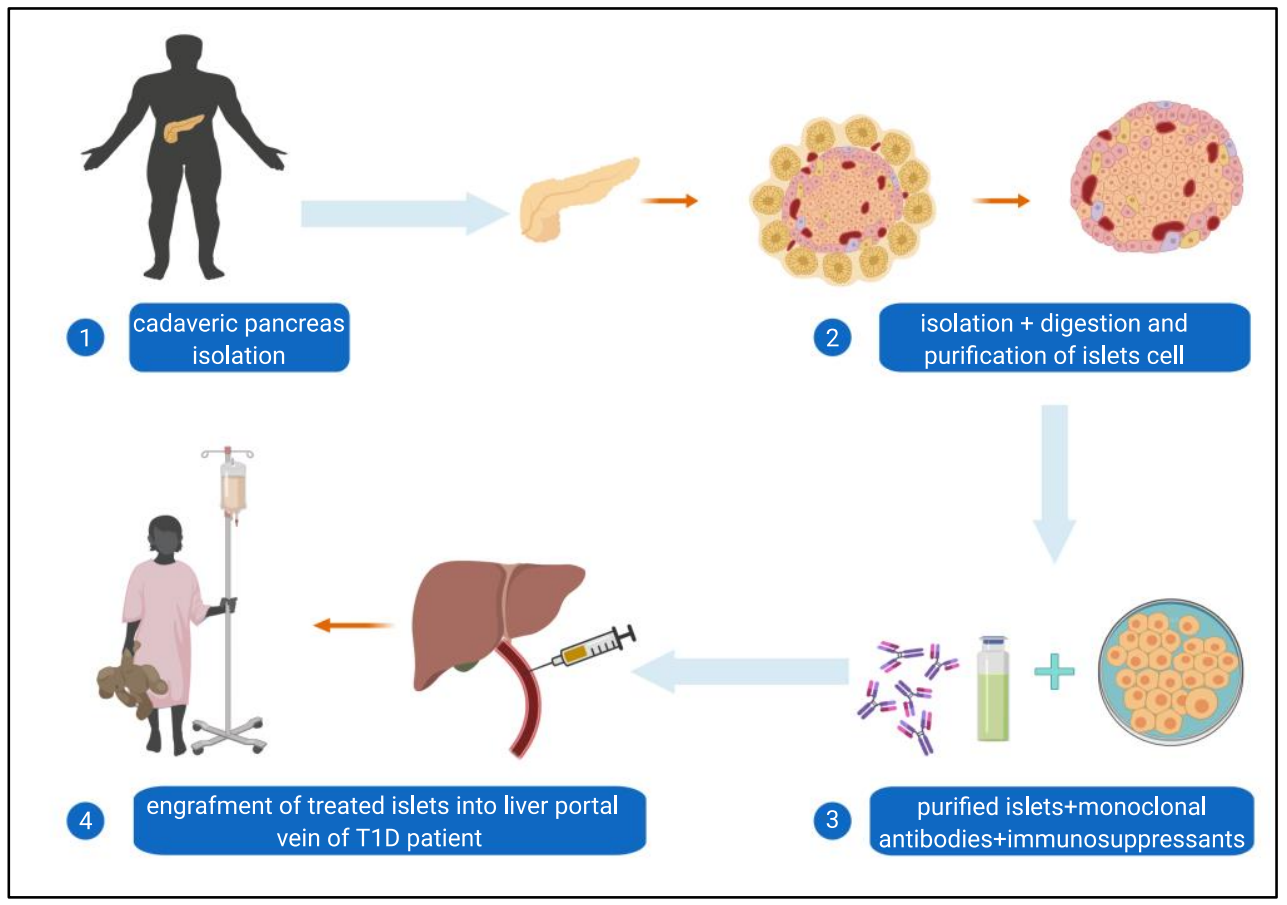

Figure 2. The Edmonton protocol relies on cadaveric islet cells that undergo several steps of digestion and purification before being cultured with immunosuppressants and monoclonal antibodies. Finally, the purified treated islets are injected into the portal vein of the liver of the T1D patient.

There is accumulating evidence that successful human islet transplantation dramatically decreases the occurrence of hypoglycemic events and reduces the frequency of long-term complications of T1D [72]. Thus, this approach might be a particularly powerful strategy for those patients with hard-to-manage T1D, enabling them to avoid or delay potentially life-threatening complications, such as renal failure. Despite this promise, $<1,000$ islet transplants have been performed in Western countries in the past 10 years, largely because of a shortage of donor organs [73], and the high cost of this therapy over traditional insulin-injection approaches [74]. One possible way of overcoming the limitations of few donor organs is to develop techniques to expand pancreatic $\beta$-cells ex vivo. Normally $\beta$-cell proliferation is restricted to a brief developmental window between birth and 1 year-of-age, but several studies have now managed to induce $\beta$-cell proliferation following a variety of genetic or pharmacologic interventions: cell division protein kinase 6 (cdk6) supported human $\beta$-cell proliferation and function in vivo [75], while aminopyrazine compounds stimulated robust $\beta$-cell proliferation in healthy adult primary islets in vitro, and these cells retained functionality in vivo after transplantation into diabetic mice [76]. Similarly, treatment with the herbal medicines, harmine, which is isolated from peganum harmala seeds, reported to possesses several pharmacological activities such as stimulate the proliferation of adult primary human $\beta$-cells grafted into diabetic mice [77]. These studies 
show the potential for expansion of functional donor $\beta$-cells that might in future enable more widespread use of islet cell transplants for patients.

In addition to the donor selection, further improvements in islet transplantation outcomes are expected as we further refine the pancreatic islet isolation technique and improve transplantation strategies including the immune suppressive protocols, islet quality, and $\beta$-cell mass and purity $[78,79]$. Moreover, the development of alternative transplantation sites and new cell sources, including porcine islet cells and the expansion of donor cells, might yet unlock an era of "on-demand" unlimited cell therapy for diabetes [80].

\subsection{Pancreatic $\beta$-Cell Regeneration and Reprogramming}

It was long held that the diabetic pancreas was devoid of functional $\beta$-cells, but there are now several lines of evidence that indicate the possibility to restore a degree of function to a T1D patient's own pancreas. This approach would have the major advantage of avoiding the need for cadaveric donors, surgery and immunosuppression. Altered $\beta$-cell identity, rather than $\beta$-cell apoptosis, in the setting of chronic hyperglycemia was first reported in Sprague-Dawley rats [81]; others subsequently reported a loss of mature $\beta$-cell identity accompanied by dedifferentiation in human Type 2 diabetes [82]. The gradual loss of $\beta$-cell-specific transcription factors (TFs) including PDX1, MAFA, and FOXO1 [83-85]; and re-expression of the developmental endocrine progenitor markers NGN3 and octamerbinding transcription factor 4 (Oct4)[86], also suggest the trans-differentiation of $\beta$-cells to a-cells in diabetic animals and humans [82, 87, 88] (Figure 3, a). 


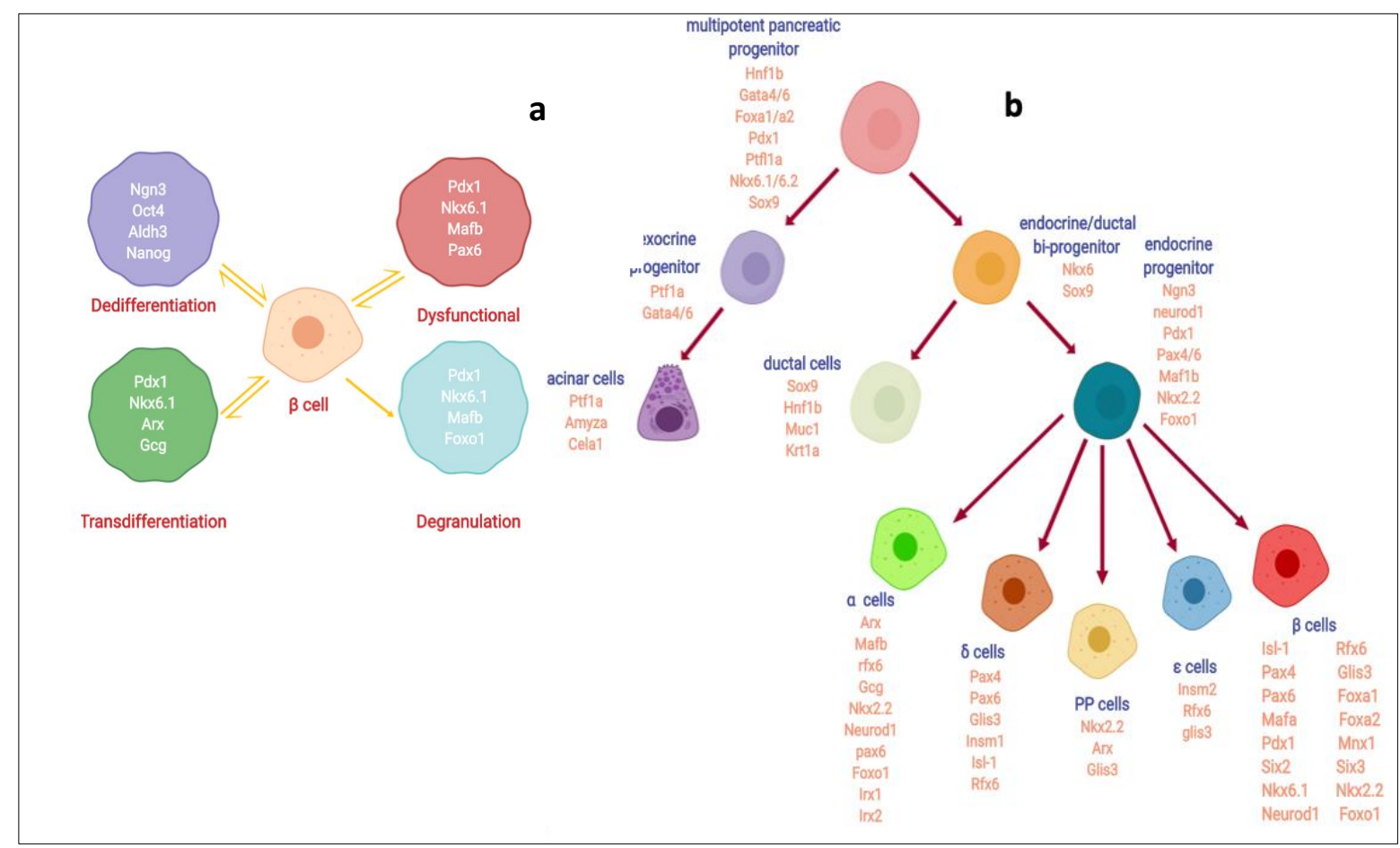

Figure 3. (a) Schematic of pancreatic cell-lineage showing the role of defined TFs. The differentiation from multipotent pancreatic progenitors to different islet cells is governed by a combination of TFs that determine the specialization of endocrine and exocrine cells. (b) Activation/repression of expression of defined sets of TFs during the determination of $\beta$-cell identity.

While the transformation of $\beta$-cells into a-cells might be considered a hallmark of T1D, the possibility of inducing the reverse process therapeutically is now starting to be explored. Collombat and colleagues demonstrated that overexpression of PAX4 [89] or selective inhibition of Aristaless Related Homeobox (ARX) [90] could induce a-cell conversion into functional $\beta$-cells and restore normoglycemia in streptozotocin-induced diabetic mice [91]. More recently, in vivo viral transduction of the TFs PDX1 and MAFA into both chemicallyinduced and autoimmune NOD mice achieved a to $\beta$-cell conversion that resulted in normoglycemia [92]. Epigenetic modification can also be used to regulate $\alpha$-cell-to- $\beta$-cell transdifferentiation. When the gene encoding Adox, a non-specific inhibitor of histone methyltransferase, was introduced into cultured human islets it induced colocalization of glucagon and insulin, and glucagon and the $\beta$-cell-specific TF Pdx1 in individual cells, indicating endocrine reprogramming consistent with transdifferentiation [93]. Importantly, it seems that age is no barrier to the potential for therapeutic transdifferentiation, as a-cells from diabetic juvenile or aged mice were equally able to undergo epigenetic reprogramming into $\beta$-cells; while in pre-pubertal diabetic mice, spontaneous $\delta$-cell to $\beta$-cell conversion occurs readily and massively [94]. Acinar cells can also be converted into $\beta$-cells either by in vivo overexpression of key $\beta$-cell TFs (PDX1, NGN3 and MAFA) leading to decreased hyperglycemia in mice [95], or by overexpression of four pancreatic TFs (PDX1, NGN3, 
PAX4 and MAFA) in human exocrine pancreatic cells leading to the generation of functional $\beta$-cell-like cells that could normalize glycemia upon transfer into diabetic mice [96]. In 2016, the same group confirmed the possibility of generating functional and clinically relevant $\beta$ cells from the human exocrine pancreas, adding Arx knockdown to the strategy [97]. Pancreatic ductal cells have also been transdifferentiated into $\beta$-cells both in vitro and in vivo in mice $[98,99]$ (Figure 3, b).

In 2018, researchers proposed that neutrophils contribute to T1D development through their role in the innate immune system [100]. Specifically, leukocytes expressing the CXCR1/2 receptor are attracted by the CXCL8 chemokine to the site of inflammation. Interfering with leukocyte homing using reparixin to disrupt the CXCR1/2 signaling pathway might, therefore, improve islet transplantation outcomes [101]. Indeed, promising effects of reparixin have been shown in terms of extending the survival time of NOD mice that have undergone islet transplantation [102]. This therapeutic strategy is currently being evaluated in phase 3 clinical trials to compare with the efficacies of standard, clinically available therapies [101].

Alongside the pathological trans-differentiation of $\beta$-cells, there is now evidence of marked heterogeneity within the $\beta$-cell pool of the T1D pancreas: data from two studies showed that most individuals with established diabetes possess a population of $\beta$-cells that can still secrete proinsulin [103] [104]. Thus, efforts to harness the potential of this population of cells are now underway. $\beta$-cells isolated by biopsy from a small cohort of newly-diagnosed adults with T1D exhibited improved functions after several days ex vivo simply by removal from the in vivo diabetogenic environment [105]. Fasting of diabetic mice also improved $\beta$-cell function, which was associated with stepwise expression of SRY-Box 17 (Sox17) and Pdx-1, followed by Ngn3-driven generation of $\beta$-like cells; recapitulating key stages of pancreatic development [106]. Importantly, applying either serum from fasting T1D patients, or fasting-mimicking medium, to human cultured T1D pancreatic islets significantly increased insulin production [106].

Epigenetic manipulations to induce $\beta$-cell proliferation are another emerging strategy that focuses on improving pancreatic differentiation protocols by influencing methylation and histone modifications of $\beta$-cell TFs. Genome-wide mapping of epigenetic marks might allow for the design of strategies that can directly modulate gene function through epigenetic control [107]. Currently available broad-acting treatments for this aim include histone deacetylase inhibitors that are designed to target apoptosis-associated cytokines [108]. Recent methodologies to control islet proliferation and biological function without 
inducing changes to the DNA sequence have used mutated transcription activator-like effector nucleases (TALENs) [109] and clustered regulatory interspaced short palindromic repeat (CRISPR)/Cas proteins. These approaches show promise to contribute to developing precision medicines in diabetes [110]

\subsection{Stem Cell Therapies}

Perhaps the most promising innovation in T1D therapy has been the exploration of the potential of stem cells. This unique population is able to self-renew indefinitely, form single cell-derived clonal cell populations, and differentiate into various cell types [111]. Stem cells from diverse sources have been investigated for their potential in $\beta$-cell regeneration (Figure 4), as discussed below.

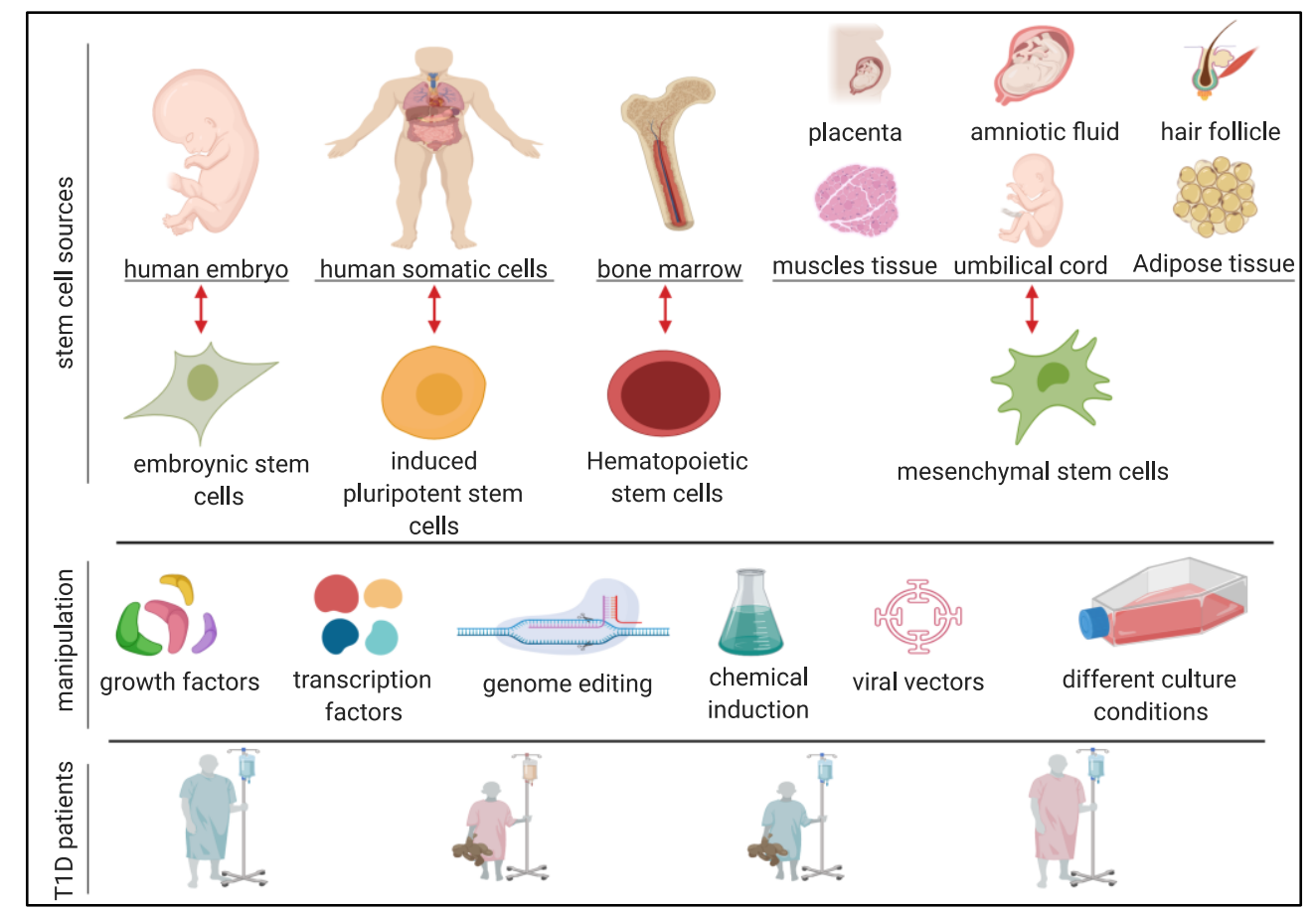

Figure 4. The various tissue sources of stem cells and different conversion methods to yield $\beta$-cell-like-cells for transplantation into T1D patients.

\subsubsection{Embryonic Stem Cells (ESCs)}

ESCs are derived from the undifferentiated inner cell mass of human embryos and have the advantage of being completely pluripotent. Several different approaches to generating insulin-producing cells (IPCs) from ESCs have been explored. Human ESCs (hESCs) in feeder-free cultures avoid the risk of animal pathogen transfer and are readily scalable, making this approach best-suited to clinical use [112]. Such a system has been successfully used to produce functional pancreatic progenitors from human ESCs. These cells have typically been cultivated using a mouse embryonic fibroblast feeder layer to support their continuous growth while in an undifferentiated state. However, the use of human ESCs in 
human therapy requires them to be free from animal cells or culturing systems, to avoid any risk of contamination with animal retroviruses. The feeder layer-free ESC culture system relies on a medium complemented with $15 \%$ serum replacement, transforming growth factor beta 1(TGF- $\beta 1$ ), basic fibroblast growth factor (bFGF), leukemia inhibitory factor (LIF) and a fibronectin (FN) matrix. All ESC features can be maintained throughout prolonged culture under these conditions, including the ability to differentiate into different tissues of the three embryonic germ layers, to maintain an unlimited and undifferentiated proliferation capacity and to retain the normal karyotype $[113,114]$.

Kroon et al. instructed the differentiation of hESCs by directly overexpressing essential $\beta$-cell TFs including PDX1, SOX9, NKX6.1 and NGN3; following engraftment into diabetic mice, the resulting cells recapitulated key features of pancreatic $\beta$-cells and protected against hyperglycemia [115]. Subsequently, an important step forwards in the use of hESCs for T1D therapy occurred when scientists from the University of British Columbia developed a seven-stage protocol that efficiently converted hESCs into IPCs. This protocol generated endocrine cells with insulin content similar to that of human islet cells and that were capable of glucose-stimulated insulin secretion in vitro as well as rapid reversal of diabetes in vivo in mice [116]. Additional studies have highlighted the possible roles of other growth and extracellular matrix factors, including laminin, nicotinamide, insulin [117] and retinoic acid [118] in the generation of IPCs from ESCs, but these findings have yet to be integrated into a combined approach suitable for clinical use.

Human ESCs also have the potential to generate cells uniquely tailored for the recipient. Recently, Sui et al. showed that transferring the nucleus of skin fibroblasts from T1D patients into hESCs gave rise to differentiated $\beta$-cells with comparable performance to naturallyoccurring $\beta$-cells when transplanted into mice [119].

Despite the promise of hESCs, great concern around their potential to initiate teratomas has largely limited their clinical exploration in T1D. However, Qadir et al. recently demonstrated a means of overcoming this risk: the authors modified hESCs to include two suicide gene cassettes, whose expression results in cell death in the presence of specific prodrugs [120]. Their method is designed to provide a double fail-safe control such that i) only IPCs survive selection; and ii) cells that may de-differentiate after transplantation can be eliminated. Furthermore, ensuring that undifferentiated cells are sensitive to two pro-drugs makes it less likely than any tumorigenic cells would survive or became resistant [121]. 


\subsubsection{Human Pluripotent Stem Cells (hPSCs)}

In vitro, a functional $\beta$-like cells from human pluripotent stem cells (hPSCs) has been successfully generated involving human embryonic stem cells (hESCs)[122-125], human induced pluripotent stem cells (hiPSCs) from patients with T1D [125, 126] and from nondiabetic donors[123, 126], and fibroblasts from non-diabetic donors [127].

Naturally, the hPSCs are immature cells that have the capacity to become nearly any cell type originated in the body. In order to impressionist the normal pancreatic cell development, a sequence of specific stages of cellular differentiations including the involvement of of certain growth factors, and signaling pathways activating/inhibiting molecules $[128,129]$.

Another approach of transplantation is through in vitro differentiated $\beta$-cells. A differentiation protocol to generate $\beta$ - like cells with enhanaced function from pancreatic progenitors through modeulating EGF- $\beta$ signaling, ceelular cluster size controlling in addition to use an enhanced serum free medica which lead to produce stem cells-derived $\beta$ cells with the ability to express $\beta$-cell markers and insulin [130, 131]. Results indiacted that certain time-frame is needed to control the TGF- $\beta$ signaling during the differentiation process in order to achieve vigorous function, which is the ultimate requirments that make these cells a promising cellular therapy for diabetes[132]

\subsubsection{Hematopoietic Stem Cells (HSCs)}

Taking a different approach, myeloablation coupled with autologous HSC transplantation aims to halt the autoimmune destruction of the pancreas and reestablish tolerance. The first autologous HSC transplantation in a T1D patient was executed by Voltarelli's group in 2007: 15 patients aged between 14-31 years and with recent T1D onset (previous 6 weeks) diagnosed by clinical findings, hyperglycemia and GAD autoantibodies (glutamic acid decarboxylase) were involved in the study [133]. When these patients were treated with autologous HSCs, most achieved insulin independence with good glycemic control lasting until the final 29.8 month follow-up, together with a notable increase in $\beta$ cell function [134]. Autologous HSC transplantation has also been used successfully to treat diabetic sequelae, including vascular complications [135] and retinopathy [136]. Other studies have focused on understanding the mechanisms underlying successful HSC transplantation in T1D: for example, Ye et al., found that autologous HSC treatment was associated with the inhibition of T-cell proliferation and pro-inflammatory cytokine production [137]; while Xiang et al. uncovered a critical role for the remaining functional $\beta$ cells on the autologous transplant of HSCs [138]. 
Despite the evident successes of autologous HSC transplantation for T1D, various complications can occur, ranging from relatively mild symptoms such as febrile neutropenia, nausea, and alopecia to more severe complications such as de novo autoimmunity and systemic infections, which in one case resulted in death $[139,140]$. The development of new strategies involving autologous HSC therapy for newly diagnosed T1D patients considering the need for multiple immunosuppressive drug approach is crucial to (1) maximize the frequency and function of $\mathrm{T}$ and $\mathrm{B}$ regulatory cells and (2) to minimize autoreactive islet-specific T and B memory cells. In this way, we should be able to improve treatment outcomes in T1D patients undergoing transplantation.

\subsubsection{Mesenchymal Stem Cells (MSCs)}

MSCs are multi-potent stromal cells able to differentiate in vitro into a range of cell types; characteristically adipocytes, chondrocytes, myocytes and osteoblasts [141]. MSCs are relatively easy to isolate from different sources in the body and numerous studies have assessed their use in T1D therapy.

Historically, the bone marrow has been the main source of MSCs [142]. Xie et al. first trialed generating IPCs from T1D patients' bone marrow MSCs (BM-MSCs) and showed the coexpression of insulin and C-peptide in cells injected into diabetic mice, leading to attenuated hyperglycemia [143]. Alongside, genetically-modified human BM-MSCs expressing vascular endothelial growth factor and PDX1 reversed hyperglycemia in more than half of diabetic mice and enabled survival and weight maintenance in all animals [144]. These promising pre-clinical results led to human trials: when BM-MSCs were injected into the splenic artery of T1D patients, they induced an increase in C-peptide levels that was maintained for 3 years; unfortunately, this had no significant effects on glycemic control due to insufficient production of insulin by the grafted cells [145]. Since then, new methods have been developed aiming to improve in vivo outcomes. For example, Zhang et al. co-cultured BM-MSCs with pancreatic stem cells which led the MSCs to adopt a pancreatic islet morphology; when these cells were injected into diabetic rats they attenuated glycated albumin levels and significantly increased serum insulin and C-peptide [146].

The main disadvantage of BM-MSCs is the difficulty in isolating the cells and the morbidity associated with the procedure. These issues led to interest in the use of Muscle-Derived 
Stem/Progenitor Cells (MDSPCs), which exist in skeletal muscle and have the capacity for long-term proliferation, are resistant to oxidative and inflammatory stress, and show multilineage differentiation potential [147]. To investigate the therapeutic potential of autologous MDSPCs transplantation for T1D, Lan et al. applied a four-stage MDSPC differentiation protocol to generate IPCs in vitro and injected them into diabetic mice: these $\beta$-cell-like-cells effectively improved hyperglycemia and glucose intolerance and increased the survival rate in diabetic mice without the use of immunosuppressants [148].

Building on the promise of BM-MSCs and MDSPCs, researchers sought an equally potent but more abundant and easily-accessed source of stem cells. Adipose-Derived Stem Cells (ADSCs) have recently been explored for T1D treatment, and have the advantage over MDSPCs of being readily accessible and harvested, even in older patients [149]. IPCs differentiated from ADSCs show significant expression of $\beta$-cell markers, insulin and cpeptide following transfer into diabetic mice [150]. In 2019, IPCs derived from ADSCs using a novel 3D xeno-antigen-free protocol were shown to exhibit key features of pancreatic $\beta$ cells in vitro and differentiated into IPCs in diabetic nude mice in vivo [151]. Another study showed the potential for combining ADSC treatment with gene therapy by transducing ADSC with a furin-cleavable insulin gene which led to enhanced insulin expression in the differentiated adipocytes, and alleviated hyperglycemia in diabetic mice [152].

Removing the need for adult stem cell donors completely, the umbilical cord is now used as a successful alternative stem cell source for regenerative medicine. Umbilical cord blood (UCB) is rich in HSCs, can be easily harvested without the need for interventions, and also contains a large number of naive functioning T-regulatory cells (Treg) with the potential to reduce auto-immunity [153, 154]. Moreover, the MSCs within UCB (UCB-MSCs) have high proliferative capacity, are easily bankable and have low tumorigenicity [155]. Together these features make UCB-MSCs the preferred option for potential T1D cell-based therapies. Studies in animal models have showed encouraging results: when Prabakar et al. adapted an ESC protocol for IPC culture and applied it to UCB-MSCs they generated expanded populations of undifferentiated IPCs expressing the key pancreatic TFs PDX1, NGN3, NEUROD1, NKX6.1, NGN3, NEUROD1, and ISL1 [156]. Following transplantation into mice, these cells subsequently differentiated into glucose-responsive IPCs [156]. Zhao et al. took a different approach to exploiting stem cells for T1D treatment, instead focusing on their capacity to downregulate immune responses. The authors achieved reversal of the autoimmune response in NOD mice by transferring autologous Tregs that had been co- 
cultured with human UCB-MSCs; this led to increased insulin secretion, reduced hyperglycemia and preservation of islet architecture [157-159].

Despite promising signs in rodent studies, the potential of UCB-MSC treatment for T1D in humans has yet to be fully realized. Haller et a, attempted the first autologous UCB-MSC transplantation in recently-diagnosed T1D patients in 2008: early indications were encouraging, with transplanted patients showing slowed loss of endogenous insulin production and an increase in peripheral blood Treg cells after 6 months [160]. However, a subsequent study by the same group found no significant difference in C-peptide levels after autologous transfusion of UCB-MSCs combined with oral docosahexaenoic acid and vitamin D supplementation [161]. Similarly, in a non-randomized controlled trial in seven new-onset T1D children who underwent autologous UCB-MSC infusion, there was no evidence of improvements in metabolic regulation or immune function at the one-year follow-up [162]. Further investigations with different parameters and larger sample sizes will be important to understand how to translate the successful application of UCB-MSC infusion from mouse to human.

Cord blood is not the only source of stem cells within the human UC: Wharton's jelly is a mucoid connective tissue in the UC that can also serve as a source of clinically-relevant MSCs (Wharton's jelly-derived mesenchymal stem cells, WJ-MSCs) for both IPC derivation and immunosuppression [163]. Briefly, WJ-MSC collection occurs at the time of delivery and avoids the known adverse effects associated with adult stem cell collection from the bone marrow or adipose tissue. Furthermore, features including a high WJ-MSC proliferation rate, an immune privileged status, minimal associated ethical concerns, and nontumorigenic capacity render these cells an excellent option to be used in regenerative medicine applications [164].

One of the first studies to use $\beta$-cell-like cells derived from WJ-MSCs tested their effects following transplantation into patients with new-onset T1D [165]. Interestingly, a concurrent study suggested that the WJ-MSCs might restore the function of $\beta$-cell in type 1 diabetic patients but it could be affected by the patient's ketoacidosis history [166], though the underlying mechanism to support this has not yet been tested. A genetically and chemically combined approach for WJ-MSC induction into IPCs has also been shown to improve the cells' homing efficiency to the pancreatic gland of diabetic rats [167]; taken 
together with a growing body of clinical data, these findings may help optimize the use of differentiated WJ-MSCs in T1D.

Undifferentiated WJ-MSCs also have the capacity to induce a protective immunesuppressive state in animal models of T1D and in patients. A study in mice performed by Tsai et al. showed that undifferentiated WJ-MSCs implanted into NOD mice both differentiated into IPCs in vivo, leading to islet repair and maintaining levels of C-peptide and insulin production, and induced beneficial immunosuppression [168]. Such evidence in rodents has since led to the initiation of human trials. A safety and dose-escalation trial is ongoing: in the first stage, Carlsson et al. are carrying out WJ-MSC allotransplantation into newly-diagnosed ( $<2$ years) T1D adult men with dose-escalation to establish safety parameters; in the second double-blinded, parallel, placebo-controlled stage, a cohort of T1D patients (men and women) will undergo WJ-MSC allotransplantation aiming to achieve immunosuppression and preserve endogenous insulin production [169]. Altogether, comparing WJ-MSCs, UCB-MSCs [170] and BM-MSCs [171], it seems that WJ-MSCs are the better anti-diabetic agents, being more homogenous and having greater potential to initiate pancreatic regeneration.

\section{Future Standpoints}

Despite advances in the various therapies discussed above, an ongoing challenge in T1D treatment is the extreme heterogeneity in patients' disease triggers, prognosis, pathological pathways and hence their response to treatment $[103,104,172,173]$; this is compounded by the recent explosion in the less-understood fulminant T1D subtype, which occurs suddenly and is associated with rapid and complete $\beta$-cell destruction [174]. This heterogeneity across the T1D patient population suggests that we are unlikely to discover a "one-size-fits-all" therapy able to cure every case: thus there is the need for more precise treatment approaches that are personalized and tailored to individual patients' situations. This is the aim of Precision Medicine [175]. In diabetes, the precision medeicine approach has been inspired by work including that of Zhao et al., who first developed stem cell educator therapy where T1D patients' lymphocytes are briefly separated from the blood and co-cultured with UC-MSCs within a closed-loop-system, before being returned to the patient; this treatment dramatically improved metabolic control, reversed autoimmunity and promoted $\beta$-cell regeneration [176]. Al-Anazi et al. used a similar approach to try and treat multiple myeloma in 45 adults with T1D who had undergone autologous HSCs; 
surprisingly the patients were also cured of their diabetes and became insulin-independent [177].

The next step towards stem-cell-mediated precision medicine for T1D is likely to involve synergizing existing stem cell approaches with advances in cellular and genetic engineering techniques, such as nuclear transfer and genome editing. Moreover, an emerging understanding of the TFs and epigenetic processes that control pancreatic islet lineage-commitment [178], as well as the role of microRNAs in driving cell lineage differentiation [179] are beginning to unlock new knowledge on T1D pathogenesis [25, 26] and are opening fresh possibilities in $\beta$-cell generation [180, 181]. New schemes conceived to regulat the immune system in T1D including the utilization of antigen-based immunotherapies[182].

Together these factors can all be used towards designing a successful protocol for precision medicine in T1D. Alongside, the reframing of T1D as primarily a metabolic disorder (rather than an autoimmune condition) that reflects the combined genomic and environmental landscape of the patient, has facilitated the discovery of new therapeutic targets and diagnostic/prognostic biomarkers [183, 184]. Finally, the ongoing discovery of new and important influences on diabetic pathology, such as the role of gut microbiota [185], $x x x x x x x x$ and the latest perceptions into the mechanism of T1D and the accumulated recent data that being translated into prospects for tissue-specific prevention trials toward eliminating progressive $\beta$-cell loss[182], continues to add to our understanding of this important disease, and thereby our ability to rationally design and test novel interventions with the promise of the future eradication of T1D (Figure 5). 


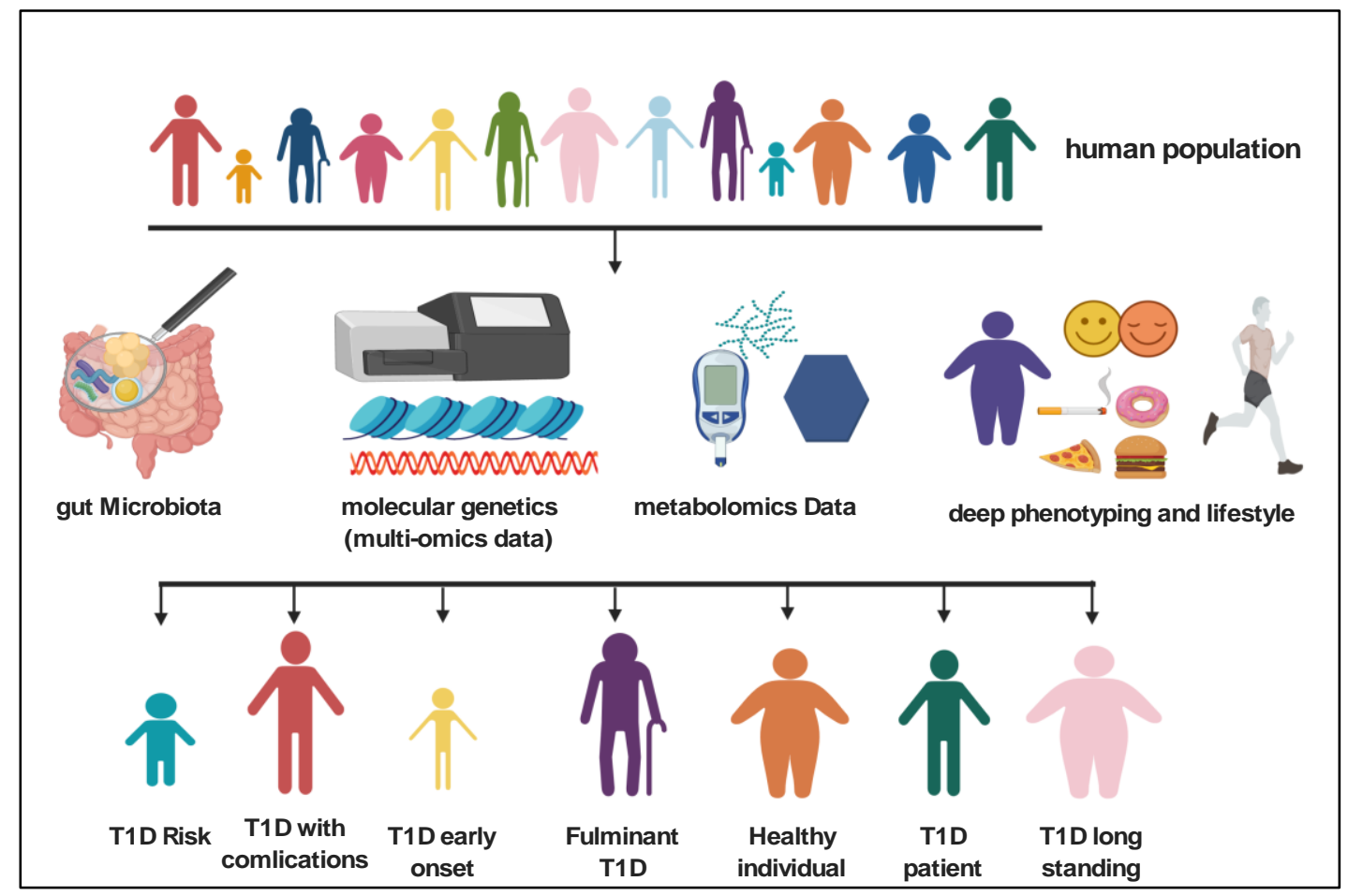

Figure 5. The multiple data sources and approaches that could efficiently connect existing factors and fill remaining knowledge gaps: together they will yield a clear diagnosis enabling tailored treatment and monitoring of responses to therapy.

Author Contributions: Original draft preparation, A.S.A.; review and editing, A.A.; K.A.; E.Y. and, K.F.; visualization, E.Y.; supervision, A.S.A.; K.F.; project administration, A.S.A.; funding acquisition, A.S.A. All authors have read and agreed to the published version of the manuscript.

Acknowledgments: We wish to thank Dr Lucy Robinson of Insight Editing London for assistance with editing support and critical reading of the manuscript prior to submission.

Funding: This research was funded by Sidra Medicine through its Precision Medicine Program Grant - SDR\#400149, Doha, Qatar.

Conflicts of Interest: The authors declare no conflict of interest.

\section{References}

1. Haller, M.J., M.A. Atkinson, and D. Schatz, Type 1 diabetes mellitus: etiology, presentation, and management. Pediatr Clin North Am, 2005. 52(6): p. 1553-78.

2. Patterson, C.C., V. Harjutsalo, J. Rosenbauer, A. Neu, O. Cinek, T. Skrivarhaug, B. Rami-Merhar, G. Soltesz, J. Svensson, R.C. Parslow, C. Castell, E.J. Schoenle, P.J. Bingley, G. Dahlquist, P.K. JaroszChobot, D. Marčiulionytė, E.F. Roche, U. Rothe, N. Bratina, C. Ionescu-Tirgoviste, I. Weets, M. Kocova, V. Cherubini, N. Rojnic Putarek, C.E. deBeaufort, M. Samardzic, and A. Green, Trends and cyclical variation in the incidence of childhood type 1 diabetes in 26 European centres in the 25 year period 1989-2013: a multicentre prospective registration study. Diabetologia, 2019. 62(3): p. 408-417. 
3. Onkamo, P., S. Väänänen, M. Karvonen, and J. Tuomilehto, Worldwide increase in incidence of Type I diabetes--the analysis of the data on published incidence trends. Diabetologia, 1999. 42(12): p. 1395-403.

4. Karvonen, M., M. Viik-Kajander, E. Moltchanova, I. Libman, R. LaPorte, and J. Tuomilehto, Incidence of childhood type 1 diabetes worldwide. Diabetes Mondiale (DiaMond) Project Group. Diabetes Care, 2000. 23(10): p. 1516.

5. Saeedi, P., I. Petersohn, P. Salpea, B. Malanda, S. Karuranga, N. Unwin, S. Colagiuri, L. Guariguata, A.A. Motala, K. Ogurtsova, J.E. Shaw, D. Bright, and R. Williams, Global and regional diabetes prevalence estimates for 2019 and projections for 2030 and 2045: Results from the International Diabetes Federation Diabetes Atlas, $9<$ sup $>$ th $</$ sup $>$ edition. Diabetes Research and Clinical Practice, 2019. 157.

6. Mayer-Davis, E.J., J.M. Lawrence, D. Dabelea, J. Divers, S. Isom, L. Dolan, G. Imperatore, B. Linder, S. Marcovina, D.J. Pettitt, C. Pihoker, S. Saydah, and L. Wagenknecht, Incidence Trends of Type 1 and Type 2 Diabetes among Youths, 2002-2012. New England Journal of Medicine, 2017. 376(15): p. 1419-1429.

7. Norris, J.M., R.K. Johnson, and L.C. Stene, Type 1 diabetes-early life origins and changing epidemiology. Lancet Diabetes Endocrinol, 2020. 8(3): p. 226-238.

8. Chandra, R. and R.A. Liddle, Neural and hormonal regulation of pancreatic secretion. Current opinion in gastroenterology, 2009. 25(5): p. 441-446.

9. Mastracci, T.L. and L. Sussel, The Endocrine Pancreas: insights into development, differentiation and diabetes. Wiley interdisciplinary reviews. Membrane transport and signaling, 2012. 1(5): p. 609-628.

10. Rewers, M. and J. Ludvigsson, Environmental risk factors for type 1 diabetes. Lancet (London, England), 2016. 387(10035): p. 2340-2348.

11. Leonard, M.M., A. Sapone, C. Catassi, and A. Fasano, Celiac disease and nonceliac gluten sensitivity: a review. Jama, 2017. 318(7): p. 647-656.

12. Grammatiki, M., E. Rapti, S. Karras, R. Ajjan, and K. Kotsa, Vitamin D and diabetes mellitus: Causal or casual association? Reviews in Endocrine and Metabolic Disorders, 2017. 18(2): p. 227-241.

13. Knip, M. and H. Siljander, The role of the intestinal microbiota in type 1 diabetes mellitus. Nature Reviews Endocrinology, 2016. 12(3): p. 154.

14. Hviid, A., M. Stellfeld, J. Wohlfahrt, and M. Melbye, Childhood vaccination and type 1 diabetes. New England Journal of Medicine, 2004. 350(14): p. 1398-1404.

15. Butalia, S., G.G. Kaplan, B. Khokhar, and D.M. Rabi, Environmental Risk Factors and Type 1 Diabetes: Past, Present, and Future. Canadian Journal of Diabetes, 2016. 40(6): p. 586-593.

16. Kolb, H. and R. Elliott, Increasing incidence of IDDM a consequence of improved hygiene? Diabetologia, 1994. 37(7): p. 729-729.

17. Baschal, E.E. and G.S. Eisenbarth, Extreme genetic risk for type $1 A$ diabetes in the post-genome era. Journal of autoimmunity, 2008. 31(1): p. 1-6.

18. Beyan, H., L. Wen, and R.D. Leslie, Guts, germs, and meals: the origin of type 1 diabetes. Curr Diab Rep, 2012. 12(5): p. 456-62.

19. Hu, C., F.S. Wong, and L. Wen, Type 1 diabetes and gut microbiota: Friend or foe? Pharmacological research, 2015. 98: p. 9-15.

20. Richardson, S.J., A. Willcox, A.J. Bone, A.K. Foulis, and N.G. Morgan, The prevalence of enteroviral capsid protein op1 immunostaining in pancreatic islets in human type 1 diabetes. Diabetologia, 2009. 52(6): p. 114351.

21. Yeung, W.C., W.D. Rawlinson, and M.E. Craig, Enterovirus infection and type 1 diabetes mellitus: systematic review and meta-analysis of observational molecular studies. Bmj, 2011. 342: p. d35. 
22. Tauriainen, S., S. Oikarinen, M. Oikarinen, and H. Hyoty, Enteroviruses in the pathogenesis of type 1 diabetes. Semin Immunopathol, 2011. 33(1): p. 45-55.

23. Rakyan, V.K., H. Beyan, T.A. Down, M.I. Hawa, S. Maslau, D. Aden, A. Daunay, F. Busato, C.A. Mein, B. Manfras, K.R. Dias, C.G. Bell, J. Tost, B.O. Boehm, S. Beck, and R.D. Leslie, Identification of type 1 diabetes-associated DNA methylation variable positions that precede disease diagnosis. PLoS Genet, 2011. 7(9): p. e1002300.

24. Miao, F., Z. Chen, S. Genuth, A. Paterson, L. Zhang, X. Wu, S.M. Li, P. Cleary, A. Riggs, D.M. Harlan, G. Lorenzi, O. Kolterman, W. Sun, J.M. Lachin, and R. Natarajan, Evaluating the role of epigenetic histone modifications in the metabolic memory of type 1 diabetes. Diabetes, 2014. 63(5): p. 1748-62.

25. Jerram, S.T., M.N. Dang, and R.D. Leslie, The Role of Epigenetics in Type 1 Diabetes. Current diabetes reports, 2017. 17(10): p. 89-89.

26. Garcia-Contreras, M., S.H. Shah, A. Tamayo, P.D. Robbins, R.B. Golberg, A.J. Mendez, and C. Ricordi, Plasma-derived exosome characterization reveals a distinct microRNA signature in long duration Type 1 diabetes. Sci Rep, 2017. 7(1): p. 5998.

27. Craig, M.E., K.W. Kim, S.R. Isaacs, M.A. Penno, E.E. Hamilton-Williams, J.J. Couper, and W.D. Rawlinson, Early-life factors contributing to type 1 diabetes. Diabetologia, 2019. 62(10): p. 1823-1834.

28. McAdams, B.H. and A.A. Rizvi, An Overview of Insulin Pumps and Glucose Sensors for the Generalist. Journal of clinical medicine, 2016. 5(1): p. 5.

29. Beck, R.W., T. Riddlesworth, K. Ruedy, A. Ahmann, R. Bergenstal, S. Haller, C. Kollman, D. Kruger, J.B. McGill, W. Polonsky, E. Toschi, H. Wolpert, and D. Price, Effect of Continuous Glucose Monitoring on Glycemic Control in Adults With Type 1 Diabetes Using Insulin Injections: The DIAMOND Randomized Clinical Trial. Jama, 2017. 317(4): p. 371-378.

30. Maiorino, M.I., S. Signoriello, A. Maio, P. Chiodini, G. Bellastella, L. Scappaticcio, M. Longo, D. Giugliano, and K. Esposito, Effects of Continuous Glucose Monitoring on Metrics of Glycemic Control in Diabetes: A Systematic Review With Meta-analysis of Randomized Controlled Trials. Diabetes Care, 2020. 43(5): p. 1146.

31. Umpierrez, G.E. and D.C. Klonoff, Diabetes Technology Update: Use of Insulin Pumps and Continuous Glucose Monitoring in the Hospital. Diabetes Care, 2018. 41(8): p. 1579-1589.

32. Sherr, J.L., M. Tauschmann, T. Battelino, M. de Bock, G. Forlenza, R. Roman, K.K. Hood, and D.M. Maahs, ISPAD clinical practice consensus guidelines 2018: diabetes technologies. Pediatric diabetes, 2018. 19: p. 302-325.

33. DeSalvo, D.J., K.M. Miller, J.M. Hermann, D.M. Maahs, S.E. Hofer, M.A. Clements, E. Lilienthal, J.L. Sherr, M. Tauschmann, R.W. Holl, t.T.D. Exchange, and D. Registries, Continuous glucose monitoring and glycemic control among youth with type 1 diabetes: International comparison from the T1D Exchange and DPV Initiative. Pediatric Diabetes, 2018. 19(7): p. 1271-1275.

34. Boughton, C.K. and R. Hovorka, Is an artificial pancreas (closed-loop system) for Type 1 diabetes effective? Diabet Med, 2019. 36(3): p. 279-286.

35. Choi, S.B., E.S. Hong, and Y.H. Noh, Open Artificial Pancreas System Reduced Hypoglycemia and Improved Glycemic Control in Patients with Type 1 Diabetes. Diabetes, 2018. 67(Supplement 1): p. 964-P.

36. Veiseh, O., B.C. Tang, K.A. Whitehead, D.G. Anderson, and R. Langer, Managing diabetes with nanomedicine: challenges and opportunities. Nature reviews. Drug discovery, 2015. 14(1): p. 45-57.

37. Zhao, L., L. Wang, Y. Zhang, S. Xiao, F. Bi, J. Zhao, G. Gai, and J. Ding, Glucose Oxidase-Based GlucoseSensitive Drug Delivery for Diabetes Treatment. Polymers, 2017. 9(7): p. 255. 
38. Primavera, R., B.D. Kevadiya, G. Swaminathan, R.J. Wilson, A. De Pascale, P. Decuzzi, and A.S. Thakor, Emerging Nano- and Micro-Technologies Used in the Treatment of Type-1 Diabetes. Nanomaterials (Basel), 2020. 10(4).

39. Neves, L.S., M.T. Rodrigues, R.L. Reis, and M.E. Gomes, Current approaches and future perspectives on strategies for the development of personalized tissue engineering therapies. Expert Review of Precision Medicine and Drug Development, 2016. 1(1): p. 93-108.

40. Chhabra, P. and K.L. Brayman, Stem Cell Therapy to Cure Type 1 Diabetes: From Hype to Hope. STEM CELLS Translational Medicine, 2013. 2(5): p. 328-336.

41. Seerup Frandsen, C., T. Dejgaard, and S. Madsbad, Non-insulin drugs to treat hyperglycaemia in type 1 diabetes mellitus. The Lancet Diabetes \& Endocrinology, 2016. 4.

42. Meng, H., A. Zhang, Y. Liang, J. Hao, X. Zhang, and J. Lu, Effect of metformin on glycaemic control in patients with type 1 diabetes: A meta-analysis of randomized controlled trials. Diabetes Metab Res Rev, 2018. 34(4): p. e2983.

43. Hoogwerf, B.J., K.B. Doshi, and D. Diab, Pramlintide, the synthetic analogue of amylin: physiology, pathophysiology, and effects on glycemic control, body weight, and selected biomarkers of vascular risk. Vasc Health Risk Manag, 2008. 4(2): p. 355-62.

44. Wang, W., H. Liu, S. Xiao, S. Liu, X. Li, and P. Yu, Effects of Insulin Plus Glucagon-Like Peptide-1 Receptor Agonists (GLP-1RAs) in Treating Type 1 Diabetes Mellitus: A Systematic Review and Meta-Analysis. Diabetes Ther, 2017. 8(4): p. 727-738.

45. Underland, L.J., J.T. Ilkowitz, R. Katikaneni, A. Dowd, and R.A. Heptulla, Use of Sitagliptin With ClosedLoop Technology to Decrease Postprandial Blood Glucose in Type 1 Diabetes. J Diabetes Sci Technol, 2017. 11(3): p. 602-610.

46. Guo, H., C. Fang, Y. Huang, Y. Pei, L. Chen, and J. Hu, The efficacy and safety of DPP4 inhibitors in patients with type 1 diabetes: A systematic review and meta-analysis. Diabetes Res Clin Pract, 2016. 121: p. 184-191.

47. Dellepiane, S., M. Ben Nasr, E. Assi, V. Usuelli, T. Letizia, F. D'Addio, G.V. Zuccotti, and P. Fiorina, Sodium glucose cotransporters inhibitors in type 1 diabetes. Pharmacol Res, 2018. 133: p. 1-8.

48. Chellappan, D.K., N.S. Sivam, K.X. Teoh, W.P. Leong, T.Z. Fui, K. Chooi, N. Khoo, F.J. Yi, J. Chellian, L.L. Cheng, R. Dahiya, G. Gupta, G. Singhvi, S. Nammi, P.M. Hansbro, and K. Dua, Gene therapy and type 1 diabetes mellitus. Biomed Pharmacother, 2018. 108: p. 1188-1200.

49. Mallol, C., E. Casana, V. Jimenez, A. Casellas, V. Haurigot, C. Jambrina, V. Sacristan, M. Morro, J. Agudo, L. Vila, and F. Bosch, AAV-mediated pancreatic overexpression of Igf1 counteracts progression to autoimmune diabetes in mice. Mol Metab, 2017. 6(7): p. 664-680.

50. Cheung, A.T., B. Dayanandan, J.T. Lewis, G.S. Korbutt, R.V. Rajotte, M. Bryer-Ash, M.O. Boylan, M.M. Wolfe, and T.J. Kieffer, Glucose-dependent insulin release from genetically engineered K cells. Science, 2000. 290(5498): p. 1959-62.

51. Chen, R., M.L. Meseck, and S.L. Woo, Auto-regulated hepatic insulin gene expression in type 1 diabetic rats. Mol Ther, 2001. 3(4): p. 584-90.

52. Jaen, M.L., L. Vila, I. Elias, V. Jimenez, J. Rodo, L. Maggioni, R. Ruiz-de Gopegui, M. Garcia, S. Munoz, D. Callejas, E. Ayuso, T. Ferre, I. Grifoll, A. Andaluz, J. Ruberte, V. Haurigot, and F. Bosch, Long-Term Efficacy and Safety of Insulin and Glucokinase Gene Therapy for Diabetes: 8-Year Follow-Up in Dogs. Mol Ther Methods Clin Dev, 2017. 6: p. 1-7.

53. Ramshur, E.B., T.R. Rull, and B.M. Wice, Novel insulin/GIP co-producing cell lines provide unexpected insights into Gut K-cell function in vivo. J Cell Physiol, 2002. 192(3): p. 339-50. 
54. Ren, B., B.A. O'Brien, M.A. Swan, M.E. Koina, N. Nassif, M.Q. Wei, and A.M. Simpson, Long-term correction of diabetes in rats after lentiviral hepatic insulin gene therapy. Diabetologia, 2007. 50(9): p. 19101920.

55. Touchefeu, Y., K.J. Harrington, J.P. Galmiche, and G. Vassaux, Review article: gene therapy, recent developments and future prospects in gastrointestinal oncology. Aliment Pharmacol Ther, 2010. 32(8): p. 95368.

56. Gan, S.U., Z. Fu, K.C. Sia, O.L. Kon, R. Calne, and K.O. Lee, Development of a liver-specific Tet-off AAV8 vector for improved safety of insulin gene therapy for diabetes. The Journal of Gene Medicine, 2019. 21(1): p. e3067.

57. Lin, Y. and Z. Sun, Antiaging Gene Klotho Attenuates Pancreatic $\beta$-Cell Apoptosis in Type 1 Diabetes. Diabetes, 2015. 64(12): p. 4298-4311.

58. Lim, K., A. Groen, G. Molostvov, T. Lu, K.S. Lilley, D. Snead, S. James, I.B. Wilkinson, S. Ting, L.-L. Hsiao, T.F. Hiemstra, and D. Zehnder, $\alpha$-Klotho Expression in Human Tissues. The Journal of Clinical Endocrinology \& Metabolism, 2015. 100(10): p. E1308-E1318.

59. Prud'homme, G.J., Y. Glinka, M. Kurt, W. Liu, and Q. Wang, The anti-aging protein Klotho is induced by GABA therapy and exerts protective and stimulatory effects on pancreatic beta cells. Biochem Biophys Res Commun, 2017. 493(4): p. 1542-1547.

60. Xie, A., R. Li, T. Jiang, H. Yan, H. Zhang, Y. Yang, L. Yang, V. Yechoor, L. Chan, and W. Chen, AntiTCRbeta mAb in Combination With Neurogenin3 Gene Therapy Reverses Established Overt Type 1 Diabetes in Female NOD Mice. Endocrinology, 2017. 158(10): p. 3140-3151.

61. Magistrelli, G., P. Jeannin, N. Herbault, A. Benoit De Coignac, J.F. Gauchat, J.Y. Bonnefoy, and Y. Delneste, A soluble form of CTLA-4 generated by alternative splicing is expressed by nonstimulated human $T$ cells. Eur J Immunol, 1999. 29(11): p. 3596-602.

62. Mourich, D.V., S.K. Oda, F.J. Schnell, S.L. Crumley, L.L. Hauck, C.A. Moentenich, N.B. Marshall, D.J. Hinrichs, and P.L. Iversen, Alternative splice forms of CTLA-4 induced by antisense mediated splice-switching influences autoimmune diabetes susceptibility in NOD mice. Nucleic Acid Ther, 2014. 24(2): p. 114-26.

63. Casanova, D., Pancreas transplantation: 50 years of experience. Cir Esp, 2017. 95(5): p. 254-260.

64. Gruessner, A.C., D.E. Sutherland, and R.W. Gruessner, Long-term outcome after pancreas transplantation. Curr Opin Organ Transplant, 2012. 17(1): p. 100-5.

65. Sutherland, D.E., R.W. Gruessner, D.L. Dunn, A.J. Matas, A. Humar, R. Kandaswamy, S.M. Mauer, W.R. Kennedy, F.C. Goetz, R.P. Robertson, A.C. Gruessner, and J.S. Najarian, Lessons learned from more than 1,000 pancreas transplants at a single institution. Annals of surgery, 2001. 233(4): p. 463-501.

66. Scharp, D.W., P.E. Lacy, J.V. Santiago, C.S. McCullough, L.G. Weide, L. Falqui, P. Marchetti, R.L. Gingerich, A.S. Jaffe, P.E. Cryer, and et al., Insulin independence after islet transplantation into type I diabetic patient. Diabetes, 1990. 39(4): p. 515-8.

67. Soon-Shiong, P., R.E. Heintz, N. Merideth, Q.X. Yao, Z. Yao, T. Zheng, M. Murphy, M.K. Moloney, M. Schmehl, M. Harris, and et al., Insulin independence in a type 1 diabetic patient after encapsulated islet transplantation. Lancet, 1994. 343(8903): p. 950-1.

68. Ricordi, C. and T.B. Strom, Clinical islet transplantation: advances and immunological challenges. Nat Rev Immunol, 2004. 4(4): p. 259-68.

69. Ryan, E.A., B.W. Paty, P.A. Senior, D. Bigam, E. Alfadhli, N.M. Kneteman, J.R.T. Lakey, and A.M.J. Shapiro, Five-Year Follow-Up After Clinical Islet Transplantation. Diabetes, 2005. 54(7): p. 2060-2069. 
70. Shapiro, A.M., J.R. Lakey, E.A. Ryan, G.S. Korbutt, E. Toth, G.L. Warnock, N.M. Kneteman, and R.V. Rajotte, Islet transplantation in seven patients with type 1 diabetes mellitus using a glucocorticoid-free immunosuppressive regimen. N Engl J Med, 2000. 343(4): p. 230-8.

71. Shapiro, A.M., C. Ricordi, B.J. Hering, H. Auchincloss, R. Lindblad, R.P. Robertson, A. Secchi, M.D. Brendel, T. Berney, D.C. Brennan, E. Cagliero, R. Alejandro, E.A. Ryan, B. DiMercurio, P. Morel, K.S. Polonsky, J.A. Reems, R.G. Bretzel, F. Bertuzzi, T. Froud, R. Kandaswamy, D.E. Sutherland, G. Eisenbarth, M. Segal, J. Preiksaitis, G.S. Korbutt, F.B. Barton, L. Viviano, V. Seyfert-Margolis, J. Bluestone, and J.R. Lakey, International trial of the Edmonton protocol for islet transplantation. N Engl J Med, 2006. 355(13): p. 1318-30.

72. Pepper, A.R., B. Gala-Lopez, O. Ziff, and A.J. Shapiro, Current status of clinical islet transplantation. World J Transplant, 2013. 3(4): p. 48-53.

73. van der Windt, D.J., R. Bottino, G. Kumar, M. Wijkstrom, H. Hara, M. Ezzelarab, B. Ekser, C. Phelps, N. Murase, A. Casu, D. Ayares, F.G. Lakkis, M. Trucco, and D.K. Cooper, Clinical islet xenotransplantation: how close are we? Diabetes, 2012. 61(12): p. 3046-55.

74. Wallner, K., A.M.J. Shapiro, P.A. Senior, and C. McCabe, Cost effectiveness and value of information analyses of islet cell transplantation in the management of 'unstable' type 1 diabetes mellitus. BMC Endocrine Disorders, 2016. 16(1): p. 17.

75. Fiaschi-Taesch, N.M., F. Salim, J. Kleinberger, R. Troxell, I. Cozar-Castellano, K. Selk, E. Cherok, K.K. Takane, D.K. Scott, and A.F. Stewart, Induction of human beta-cell proliferation and engraftment using a single G1/S regulatory molecule, cdk6. Diabetes, 2010. 59(8): p. 1926-1936.

76. Shen, W., B. Taylor, Q. Jin, V. Nguyen-Tran, S. Meeusen, Y.Q. Zhang, A. Kamireddy, A. Swafford, A.F. Powers, J. Walker, J. Lamb, B. Bursalaya, M. DiDonato, G. Harb, M. Qiu, C.M. Filippi, L. Deaton, C.N. Turk, W.L. Suarez-Pinzon, Y. Liu, X. Hao, T. Mo, S. Yan, J. Li, A.E. Herman, B.J. Hering, T. Wu, H. Martin Seidel, P. McNamara, R. Glynne, and B. Laffitte, Inhibition of DYRK1A and GSK3B induces human beta-cell proliferation. Nat Commun, 2015. 6: p. 8372.

77. Wang, P., J.C. Alvarez-Perez, D.P. Felsenfeld, H. Liu, S. Sivendran, A. Bender, A. Kumar, R. Sanchez, D.K. Scott, A. Garcia-Ocana, and A.F. Stewart, A high-throughput chemical screen reveals that harminemediated inhibition of DYRK1A increases human pancreatic beta cell replication. Nat Med, 2015. 21(4): p. 3838.

78. Vantyghem, M.-C., E.J. de Koning, F. Pattou, and M.R. Rickels, Advances in $\beta$-cell replacement therapy for the treatment of type 1 diabetes. The Lancet, 2019. 394(10205): p. 1274-1285.

79. Roep, B.O., Improving Clinical Islet Transplantation Outcomes. Diabetes Care, 2020. 43(4): p. 698-700.

80. Rickels, M.R. and R.P. Robertson, Pancreatic Islet Transplantation in Humans: Recent Progress and Future Directions. Endocrine Reviews, 2018. 40(2): p. 631-668.

81. Jonas, J.C., A. Sharma, W. Hasenkamp, H. Ilkova, G. Patane, R. Laybutt, S. Bonner-Weir, and G.C. Weir, Chronic hyperglycemia triggers loss of pancreatic beta cell differentiation in an animal model of diabetes. J Biol Chem, 1999. 274(20): p. 14112-21.

82. Cinti, F., R. Bouchi, J.Y. Kim-Muller, Y. Ohmura, P.R. Sandoval, M. Masini, L. Marselli, M. Suleiman, L.E. Ratner, P. Marchetti, and D. Accili, Evidence of $\beta$-Cell Dedifferentiation in Human Type 2 Diabetes. The Journal of Clinical Endocrinology \& Metabolism, 2016. 101(3): p. 1044-1054.

83. Sachdeva, M.M., K.C. Claiborn, C. Khoo, J. Yang, D.N. Groff, R.G. Mirmira, and D.A. Stoffers, $P d x 1$ $(<e m>M O D Y 4</ e m>)$ regulates pancreatic beta cell susceptibility to ER stress. Proceedings of the National Academy of Sciences, 2009. 106(45): p. 19090-19095. 
84. Kluth, O., F. Mirhashemi, S. Scherneck, D. Kaiser, R. Kluge, S. Neschen, H.G. Joost, and A. Schürmann, Dissociation of lipotoxicity and glucotoxicity in a mouse model of obesity associated diabetes: role of forkhead box O1 (FOXO1) in glucose-induced beta cell failure. Diabetologia, 2011. 54(3): p. 605-616.

85. Zhao, L., M. Guo, T.A. Matsuoka, D.K. Hagman, S.D. Parazzoli, V. Poitout, and R. Stein, The islet beta cell-enriched MafA activator is a key regulator of insulin gene transcription. J Biol Chem, 2005. 280(12): p. 11887-94.

86. Talchai, C., S. Xuan, Hua V. Lin, L. Sussel, and D. Accili, Pancreatic $\beta$ Cell Dedifferentiation as a Mechanism of Diabetic $\beta$ Cell Failure. Cell, 2012. 150(6): p. 1223-1234.

87. Spijker, H.S., R.B.G. Ravelli, A.M. Mommaas-Kienhuis, A.A. van Apeldoorn, M.A. Engelse, A. Zaldumbide, S. Bonner-Weir, T.J. Rabelink, R.C. Hoeben, H. Clevers, C.L. Mummery, F. Carlotti, and E.J.P. de Koning, Conversion of Mature Human $\beta$-Cells Into Glucagon-Producing $\alpha$-Cells. Diabetes, 2013. 62(7): p. 2471-2480.

88. Brereton, M.F., M. Iberl, K. Shimomura, Q. Zhang, A.E. Adriaenssens, P. Proks, I.I. Spiliotis, W. Dace, K.K. Mattis, R. Ramracheya, F.M. Gribble, F. Reimann, A. Clark, P. Rorsman, and F.M. Ashcroft, Reversible changes in pancreatic islet structure and function produced by elevated blood glucose. Nature Communications, 2014. 5(1): p. 4639.

89. Collombat, P., X. Xu, P. Ravassard, B. Sosa-Pineda, S. Dussaud, N. Billestrup, O.D. Madsen, P. Serup, H. Heimberg, and A. Mansouri, The Ectopic Expression of Pax4 in the Mouse Pancreas Converts Progenitor Cells into $\alpha$ and Subsequently $\beta$ Cells. Cell, 2009. 138(3): p. 449-462.

90. Courtney, M., E. Gjernes, N. Druelle, C. Ravaud, A. Vieira, N. Ben-Othman, A. Pfeifer, F. Avolio, G. Leuckx, S. Lacas-Gervais, F. Burel-Vandenbos, D. Ambrosetti, J. Hecksher-Sorensen, P. Ravassard, H. Heimberg, A. Mansouri, and P. Collombat, The Inactivation of Arx in Pancreatic $\alpha$-Cells Triggers Their Neogenesis and Conversion into Functional $\beta$-Like Cells. PLOS Genetics, 2013. 9(10): p. e1003934.

91. Thorel, F., V. Népote, I. Avril, K. Kohno, R. Desgraz, S. Chera, and P.L. Herrera, Conversion of adult pancreatic $\alpha$-cells to $\beta$-cells after extreme $\beta$-cell loss. Nature, 2010. 464: p. 1149.

92. Xiao, X., P. Guo, C. Shiota, T. Zhang, G.M. Coudriet, S. Fischbach, K. Prasadan, J. Fusco, S. Ramachandran, P. Witkowski, J.D. Piganelli, and G.K. Gittes, Endogenous Reprogramming of Alpha Cells into Beta Cells, Induced by Viral Gene Therapy, Reverses Autoimmune Diabetes. Cell Stem Cell, 2018. 22(1): p. 78-90.e4.

93. Bramswig, N.C., L.J. Everett, J. Schug, C. Dorrell, C. Liu, Y. Luo, P.R. Streeter, A. Naji, M. Grompe, and K.H. Kaestner, Epigenomic plasticity enables human pancreatic alpha to beta cell reprogramming. J Clin Invest, 2013. 123(3): p. 1275-84.

94. Chera, S., D. Baronnier, L. Ghila, V. Cigliola, J.N. Jensen, G. Gu, K. Furuyama, F. Thorel, F.M. Gribble, F. Reimann, and P.L. Herrera, Diabetes recovery by age-dependent conversion of pancreatic delta-cells into insulin producers. Nature, 2014. 514(7523): p. 503-7.

95. Zhou, Q., J. Brown, A. Kanarek, J. Rajagopal, and D.A. Melton, In vivo reprogramming of adult pancreatic exocrine cells to $\beta$-cells. Nature, 2008. 455(7213): p. 627-632.

96. Lima, M.J., K.R. Muir, H.M. Docherty, R. Drummond, N.W.A. McGowan, S. Forbes, Y. Heremans, I. Houbracken, J.A. Ross, S.J. Forbes, P. Ravassard, H. Heimberg, J. Casey, and K. Docherty, Suppression of Epithelial-to-Mesenchymal Transitioning Enhances Ex Vivo Reprogramming of Human Exocrine Pancreatic Tissue Toward Functional Insulin-Producing $\beta$-Like Cells. Diabetes, 2013. 62(8): p. 2821. 
97. Lima, M.J., K.R. Muir, H.M. Docherty, N.W.A. McGowan, S. Forbes, Y. Heremans, H. Heimberg, J. Casey, and K. Docherty, Generation of Functional Beta-Like Cells from Human Exocrine Pancreas. PLOS ONE, 2016. 11(5): p. e0156204.

98. Bonner-Weir, S., W.C. Li, L. Ouziel-Yahalom, L. Guo, G.C. Weir, and A. Sharma, Beta-cell growth and regeneration: replication is only part of the story. Diabetes, 2010. 59(10): p. 2340-8.

99. Assouline-Thomas, B., D. Ellis, M. Petropavlovskaia, J. Makhlin, J. Ding, and L. Rosenberg, Islet Neogenesis Associated Protein (INGAP) induces the differentiation of an adult human pancreatic ductal cell line into insulin-expressing cells through stepwise activation of key transcription factors for embryonic beta cell development. Differentiation, 2015. 90(4-5): p. 77-90.

100. Vecchio, F., N.L. Buono, A. Stabilini, L. Nigi, M.J. Dufort, S. Geyer, P.M. Rancoita, F. Cugnata, A. Mandelli, and A. Valle, Abnormal neutrophil signature in the blood and pancreas of presymptomatic and symptomatic type 1 diabetes. JCI insight, 2018. 3(18).

101. Maffi, P., T. Lundgren, G. Tufveson, E. Rafael, J.A. Shaw, A. Liew, F. Saudek, P. Witkowski, K. Golab, and F. Bertuzzi, Targeting CXCR1/2 does not improve insulin secretion after pancreatic islet transplantation: a phase 3, double-blind, randomized, placebo-controlled trial in type 1 diabetes. Diabetes Care, 2020. 43(4): p. 710-718.

102. Citro, A., A. Valle, E. Cantarelli, A. Mercalli, S. Pellegrini, D. Liberati, L. Daffonchio, O. Kastsiuchenka, P.A. Ruffini, and M. Battaglia, CXCR1/2 inhibition blocks and reverses type 1 diabetes in mice. Diabetes, 2015. 64(4): p. 1329-1340.

103. Sims, E.K., H.T. Bahnson, J. Nyalwidhe, L. Haataja, A.K. Davis, C. Speake, L.A. DiMeglio, J. Blum, M.A. Morris, R.G. Mirmira, J. Nadler, T.L. Mastracci, S. Marcovina, W.-J. Qian, L. Yi, A.C. Swensen, M. YipSchneider, C.M. Schmidt, R.V. Considine, P. Arvan, C.J. Greenbaum, and C. Evans-Molina, Proinsulin Secretion Is a Persistent Feature of Type 1 Diabetes. Diabetes Care, 2019. 42(2): p. 258.

104. Wasserfall, C., H.S. Nick, M. Campbell-Thompson, D. Beachy, L. Haataja, I. Kusmartseva, A. Posgai, M. Beery, C. Rhodes, E. Bonifacio, P. Arvan, and M. Atkinson, Persistence of Pancreatic Insulin mRNA Expression and Proinsulin Protein in Type 1 Diabetes Pancreata. Cell Metabolism, 2017. 26(3): p. 568-575.e3.

105. Krogvold, L., O. Skog, G. Sundström, B. Edwin, T. Buanes, K.F. Hanssen, J. Ludvigsson, M. Grabherr, O. Korsgren, and K. Dahl-Jørgensen, Function of Isolated Pancreatic Islets From Patients at Onset of Type 1 Diabetes: Insulin Secretion Can Be Restored After Some Days in a Nondiabetogenic Environment In Vitro. Diabetes, 2015. 64(7): p. 2506.

106. Cheng, C.W., V. Villani, R. Buono, M. Wei, S. Kumar, O.H. Yilmaz, P. Cohen, J.B. Sneddon, L. Perin, and V.D. Longo, Fasting-Mimicking Diet Promotes Ngn3-Driven beta-Cell Regeneration to Reverse Diabetes. Cell, 2017. 168(5): p. 775-788.e12.

107. Keating, S.T., J. Plutzky, and A. El-Osta, Epigenetic Changes in Diabetes and Cardiovascular Risk. Circulation research, 2016. 118(11): p. 1706-1722.

108. Golson, M.L. and K.H. Kaestner, Epigenetics in formation, function, and failure of the endocrine pancreas. Molecular Metabolism, 2017. 6(9): p. 1066-1076.

109. Gaj, T., C.A. Gersbach, and C.F. Barbas, ZFN, TALEN, and CRISPR/Cas-based methods for genome engineering. Trends in biotechnology, 2013. 31(7): p. 397-405.

110. Li, H., Y. Yang, W. Hong, M. Huang, M. Wu, and X. Zhao, Applications of genome editing technology in the targeted therapy of human diseases: mechanisms, advances and prospects. Signal Transduction and Targeted Therapy, 2020. 5(1): p. 1. 
111. Tran, C. and M.S. Damaser, Stem cells as drug delivery methods: application of stem cell secretome for regeneration. Advanced drug delivery reviews, 2015. 82-83: p. 1-11.

112. Lee, J.B., J.E. Lee, J.H. Park, S.J. Kim, M.K. Kim, S.I. Roh, and H.S. Yoon, Establishment and Maintenance of Human Embryonic Stem Cell Lines on Human Feeder Cells Derived from Uterine Endometrium under SerumFree Condition1. Biology of Reproduction, 2005. 72(1): p. 42-49.

113. Amit, M. and J. Itskovitz-Eldor, Feeder-free culture of human embryonic stem cells. Methods Enzymol, 2006. 420: p. 37-49.

114. Furue, M.K., J. Na, J.P. Jackson, T. Okamoto, M. Jones, D. Baker, R.-I. Hata, H.D. Moore, J.D. Sato, and P.W. Andrews, Heparin promotes the growth of human embryonic stem cells in a defined serum-free medium. Proceedings of the National Academy of Sciences, 2008. 105(36): p. 13409.

115. Kroon, E., L.A. Martinson, K. Kadoya, A.G. Bang, O.G. Kelly, S. Eliazer, H. Young, M. Richardson, N.G. Smart, J. Cunningham, A.D. Agulnick, K.A. D'Amour, M.K. Carpenter, and E.E. Baetge, Pancreatic endoderm derived from human embryonic stem cells generates glucose-responsive insulin-secreting cells in vivo. Nat Biotechnol, 2008. 26(4): p. 443-52.

116. Rezania, A., J.E. Bruin, P. Arora, A. Rubin, I. Batushansky, A. Asadi, S. O'Dwyer, N. Quiskamp, M. Mojibian, T. Albrecht, Y.H.C. Yang, J.D. Johnson, and T.J. Kieffer, Reversal of diabetes with insulinproducing cells derived in vitro from human pluripotent stem cells. Nature Biotechnology, 2014. 32: p. 1121.

117. Schroeder, I.S., A. Rolletschek, P. Blyszczuk, G. Kania, and A.M. Wobus, Differentiation of mouse embryonic stem cells to insulin-producing cells. Nat Protoc, 2006. 1(2): p. 495-507.

118. Cai, J., C. Yu, Y. Liu, S. Chen, Y. Guo, J. Yong, W. Lu, M. Ding, and H. Deng, Generation of homogeneous PDX1(+) pancreatic progenitors from human ES cell-derived endoderm cells. J Mol Cell Biol, 2010. 2(1): p. 5060.

119. Sui, L., N. Danzl, S.R. Campbell, R. Viola, D. Williams, Y. Xing, Y. Wang, N. Phillips, G. Poffenberger, B. Johannesson, J. Oberholzer, A.C. Powers, R.L. Leibel, X. Chen, M. Sykes, and D. Egli, beta-Cell Replacement in Mice Using Human Type 1 Diabetes Nuclear Transfer Embryonic Stem Cells. Diabetes, 2018. 67(1): p. 26-35.

120. Qadir, M.M.F., S. Álvarez-Cubela, K. Belle, T. Sapir, F. Messaggio, K.B. Johnson, O. Umland, D. Hardin, D. Klein, I. Pérez-Álvarez, F. Sadiq, O. Alcázar, L.A. Inverardi, C. Ricordi, P. Buchwald, C.A. Fraker, R.L. Pastori, and J. Domínguez-Bendala, A Double Fail-Safe Approach to Prevent Tumorigenesis and Select Pancreatic $\beta$ Cells from Human Embryonic Stem Cells. Stem Cell Reports, 2019. 12(3): p. 611-623.

121. Kotini, A.G., E. de Stanchina, M. Themeli, M. Sadelain, and E.P. Papapetrou, Escape Mutations, Ganciclovir Resistance, and Teratoma Formation in Human iPSCs Expressing an HSVtk Suicide Gene. Molecular Therapy - Nucleic Acids, 2016. 5: p. e284.

122. Russ, H.A., A.V. Parent, J.J. Ringler, T.G. Hennings, G.G. Nair, M. Shveygert, T. Guo, S. Puri, L. Haataja, and V. Cirulli, Controlled induction of human pancreatic progenitors produces functional beta-like cells in vitro. The EMBO journal, 2015. 34(13): p. 1759-1772.

123. Rezania, A., J.E. Bruin, P. Arora, A. Rubin, I. Batushansky, A. Asadi, S. O'dwyer, N. Quiskamp, M. Mojibian, and T. Albrecht, Reversal of diabetes with insulin-producing cells derived in vitro from human pluripotent stem cells. Nature biotechnology, 2014. 32(11): p. 1121.

124. Pagliuca, F.W., J.R. Millman, M. Gürtler, M. Segel, A. Van Dervort, J.H. Ryu, Q.P. Peterson, D. Greiner, and D.A. Melton, Generation of functional human pancreatic $\beta$ cells in vitro. Cell, 2014. 159(2): p. 428-439. 
125. Vegas, A.J., O. Veiseh, M. Gürtler, J.R. Millman, F.W. Pagliuca, A.R. Bader, J.C. Doloff, J. Li, M. Chen, and K. Olejnik, Long-term glycemic control using polymer-encapsulated human stem cell-derived beta cells in immune-competent mice. Nature medicine, 2016. 22(3): p. 306.

126. Millman, J.R., C. Xie, A. Van Dervort, M. Gürtler, F.W. Pagliuca, and D.A. Melton, Generation of stem cell-derived $\beta$-cells from patients with type 1 diabetes. Nature communications, 2016. 7(1): p. 1-9.

127. Zhu, S., H.A. Russ, X. Wang, M. Zhang, T. Ma, T. Xu, S. Tang, M. Hebrok, and S. Ding, Human pancreatic beta-like cells converted from fibroblasts. Nature communications, 2016. 7(1): p. 1-13.

128. Thomson, J.A., J. Itskovitz-Eldor, S.S. Shapiro, M.A. Waknitz, J.J. Swiergiel, V.S. Marshall, and J.M. Jones, Embryonic stem cell lines derived from human blastocysts. science, 1998. 282(5391): p. 1145-1147.

129. Yu, J., M.A. Vodyanik, K. Smuga-Otto, J. Antosiewicz-Bourget, J.L. Frane, S. Tian, J. Nie, G.A. Jonsdottir, V. Ruotti, and R. Stewart, Induced pluripotent stem cell lines derived from human somatic cells. science, 2007. 318(5858): p. 1917-1920.

130. Millman, J.R. and F.W. Pagliuca, Autologous Pluripotent Stem Cell-Derived $\beta$-Like Cells for Diabetes Cellular Therapy. Diabetes, 2017. 66(5): p. 1111.

131. Velazco-Cruz, L., J. Song, K.G. Maxwell, M.M. Goedegebuure, P. Augsornworawat, N.J. Hogrebe, and J.R. Millman, Acquisition of Dynamic Function in Human Stem Cell-Derived $\beta$ Cells. Stem Cell Reports, 2019. 12(2): p. 351-365.

132. Augsornworawat, P. and J.R. Millman, Single-cell RNA sequencing for engineering and studying human islets. Current Opinion in Biomedical Engineering, 2020. 16: p. 27-33.

133. Voltarelli, J.C., C.E. Couri, A.B. Stracieri, M.C. Oliveira, D.A. Moraes, F. Pieroni, M. Coutinho, K.C. Malmegrim, M.C. Foss-Freitas, B.P. Simoes, M.C. Foss, E. Squiers, and R.K. Burt, Autologous nonmyeloablative hematopoietic stem cell transplantation in newly diagnosed type 1 diabetes mellitus. Jama, 2007. 297(14): p. 1568-76.

134. Couri, C.E., M.C. Oliveira, A.B. Stracieri, D.A. Moraes, F. Pieroni, G.M. Barros, M.I. Madeira, K.C. Malmegrim, M.C. Foss-Freitas, B.P. Simoes, E.Z. Martinez, M.C. Foss, R.K. Burt, and J.C. Voltarelli, Cpeptide levels and insulin independence following autologous nonmyeloablative hematopoietic stem cell transplantation in newly diagnosed type 1 diabetes mellitus. Jama, 2009. 301(15): p. 1573-9.

135. Penaforte-Saboia, J.G., R.M. Montenegro, Jr., C.E. Couri, L.A. Batista, A. Montenegro, V.O. Fernandes, H. Akhtar, C.A. Negrato, K.C.R. Malmegrim, D.A. Moraes, J.B.E. Dias, B.P. Simoes, M.B. Gomes, and M.C. Oliveira, Microvascular Complications in Type 1 Diabetes: A Comparative Analysis of Patients Treated with Autologous Nonmyeloablative Hematopoietic Stem-Cell Transplantation and Conventional Medical Therapy. Front Endocrinol (Lausanne), 2017. 8: p. 331.

136. Bhatwadekar, A.D., Y. Duan, M. Korah, J.S. Thinschmidt, P. Hu, S.P. Leley, S. Caballero, L. Shaw, J. Busik, and M.B. Grant, Hematopoietic stem/progenitor involvement in retinal microvascular repair during diabetes: Implications for bone marrow rejuvenation. Vision Res, 2017. 139: p. 211-220.

137. Ye, L., L. Li, B. Wan, M. Yang, J. Hong, W. Gu, W. Wang, and G. Ning, Immune response after autologous hematopoietic stem cell transplantation in type 1 diabetes mellitus. Stem Cell Research \& Therapy, 2017. 8(1): p. 90.

138. Xiang, H., C. Yang, T. Xiang, Z. Wang, X. Ge, F. Li, Y. Su, H. Chen, X. Huang, and Q. Zeng, Residual $\beta$ Cell Function Predicts Clinical Response After Autologous Hematopoietic Stem Cell Transplantation. STEM CELLS Translational Medicine, 2016. 5(5): p. 651-657.

139. Snarski, E., A. Milczarczyk, K. Hałaburda, T. Torosian, M. Paluszewska, E. Urbanowska, M. Król, P. Boguradzki, K. Jedynasty, E. Franek, and W. Wiktor-Jedrzejczak, Immunoablation and autologous 
hematopoietic stem cell transplantation in the treatment of new-onset type 1 diabetes mellitus: long-term observations. Bone Marrow Transplantation, 2016. 51(3): p. 398-402.

140. Daikeler, T., A. Tichelli, and J. Passweg, Complications of autologous hematopoietic stem cell transplantation for patients with autoimmune diseases. Pediatric Research, 2012. 71(2): p. 439-444.

141. Dominici, M., K. Le Blanc, I. Mueller, I. Slaper-Cortenbach, F. Marini, D. Krause, R. Deans, A. Keating, D. Prockop, and E. Horwitz, Minimal criteria for defining multipotent mesenchymal stromal cells. The International Society for Cellular Therapy position statement. Cytotherapy, 2006. 8(4): p. 315-7.

142. Ianus, A., G.G. Holz, N.D. Theise, and M.A. Hussain, In vivo derivation of glucose-competent pancreatic endocrine cells from bone marrow without evidence of cell fusion. The Journal of clinical investigation, 2003. 111(6): p. 843-850.

143. Xie, Q.-P., H. Huang, B. Xu, X. Dong, S.-L. Gao, B. Zhang, and Y.-L. Wu, Human bone marrow mesenchymal stem cells differentiate into insulin-producing cells upon microenvironmental manipulation in vitro. Differentiation, 2009. 77(5): p. 483-491.

144. Milanesi, A., J.-W. Lee, Z. Li, S. Da Sacco, V. Villani, V. Cervantes, L. Perin, and J.S. Yu, $\beta$-Cell Regeneration Mediated by Human Bone Marrow Mesenchymal Stem Cells. PLOS ONE, 2012. 7(8): p. e42177.

145. Ghodsi, M., R. Heshmat, M. Amoli, A.A. Keshtkar, B. Arjmand, H. Aghayan, P. Hosseini, A.M. Sharifi, and B. Larijani, The effect of fetal liver-derived cell suspension allotransplantation on patients with diabetes: first year of follow-up. Acta Med Iran, 2012. 50(8): p. 541-6.

146. Zhang, J., R. Mao, X. Wang, K. Liu, Q. Geng, Y. Yu, Y. Li, and J. Qi, Targeted induction of bone marrow mesenchymal stem cells to have effectiveness on diabetic pancreatic restoration. In Vitro Cellular \& Developmental Biology - Animal, 2019. 55(6): p. 453-461.

147. Qu-Petersen, Z., B. Deasy, R. Jankowski, M. Ikezawa, J. Cummins, R. Pruchnic, J. Mytinger, B. Cao, C. Gates, A. Wernig, and J. Huard, Identification of a novel population of muscle stem cells in mice. potential for muscle regeneration, 2002. 157(5): p. 851-864.

148. Lan, K.C., C.C. Wang, Y.P. Yen, R.S. Yang, S.H. Liu, and D.C. Chan, Islet-like clusters derived from skeletal muscle-derived stem/progenitor cells for autologous transplantation to control type 1 diabetes in mice. Artif Cells Nanomed Biotechnol, 2018. 46(sup3): p. S328-s335.

149. Sterodimas, A., J. de Faria, B. Nicaretta, and I. Pitanguy, Tissue engineering with adipose-derived stem cells (ADSCs): current and future applications. J Plast Reconstr Aesthet Surg, 2010. 63(11): p. 1886-92.

150. Amer, M.G., A.S. Embaby, R.A. Karam, and M.G. Amer, Role of adipose tissue derived stem cells differentiated into insulin producing cells in the treatment of type I diabetes mellitus. Gene, 2018. 654: p. 87-94.

151. Ikemoto, T., R. Feng, S.I. Iwahashi, S. Yamada, Y. Saito, Y. Morine, S. Imura, M. Matsuhisa, and M. Shimada, In vitro and in vivo effects of insulin-producing cells generated by xeno-antigen free $3 D$ culture with RCP piece. Sci Rep, 2019. 9(1): p. 10759.

152. Fang, Q., M. Zhai, S. Wu, X. Hu, Z. Hua, H. Sun, J. Guo, W. Zhang, and Z. Wang, Adipocyte-derived stem cell-based gene therapy upon adipogenic differentiation on microcarriers attenuates type 1 diabetes in mice. Stem Cell Res Ther, 2019. 10(1): p. 36.

153. Dessels, C., M. Alessandrini, and M.S. Pepper, Factors Influencing the Umbilical Cord Blood Stem Cell Industry: An Evolving Treatment Landscape. STEM CELLS Translational Medicine, 2018. 7(9): p. 643-650.

154. Kim, Y.-J. and H.E. Broxmeyer, Immune regulatory cells in umbilical cord blood and their potential roles in transplantation tolerance. Critical Reviews in Oncology/Hematology, 2011. 79(2): p. 112-126.

155. Arutyunyan, I., A. Elchaninov, A. Makarov, and T. Fatkhudinov, Umbilical Cord as Prospective Source for Mesenchymal Stem Cell-Based Therapy. Stem Cells Int, 2016. 2016: p. 6901286. 
156. Prabakar, K.R., J. Domínguez-Bendala, R.D. Molano, A. Pileggi, S. Villate, C. Ricordi, and L. Inverardi, Generation of Glucose-Responsive, Insulin-Producing Cells from Human Umbilical Cord Blood-Derived Mesenchymal Stem Cells. Cell Transplantation, 2012. 21(6): p. 1321-1339.

157. Zhao, Y., B. Lin, R. Darflinger, Y. Zhang, M.J. Holterman, and R.A. Skidgel, Human Cord Blood Stem CellModulated Regulatory T Lymphocytes Reverse the Autoimmune-Caused Type 1 Diabetes in Nonobese Diabetic (NOD) Mice. PLOS ONE, 2009. 4(1): p. e4226.

158. Zhao, Y., Z. Jiang, T. Zhao, M. Ye, C. Hu, Z. Yin, H. Li, Y. Zhang, Y. Diao, and Y. Li, Reversal of type 1 diabetes via islet $\beta$ cell regeneration following immune modulation by cord blood-derived multipotent stem cells. BMC medicine, 2012. 10(1): p. 1-11.

159. Cai, J., Z. Wu, X. Xu, L. Liao, J. Chen, L. Huang, W. Wu, F. Luo, C. Wu, and A. Pugliese, Umbilical cord mesenchymal stromal cell with autologous bone marrow cell transplantation in established type 1 diabetes: a pilot randomized controlled open-label clinical study to assess safety and impact on insulin secretion. Diabetes care, 2016. 39(1): p. 149-157.

160. Haller, M.J., H.-L. Viener, C. Wasserfall, T. Brusko, M.A. Atkinson, and D.A. Schatz, Autologous umbilical cord blood infusion for type 1 diabetes. Experimental hematology, 2008. 36(6): p. 710-715.

161. Haller, M.J., C.H. Wasserfall, M.A. Hulme, M. Cintron, T.M. Brusko, K.M. McGrail, J.R. Wingard, D.W. Theriaque, J.J. Shuster, R.J. Ferguson, M. Kozuch, M. Clare-Salzler, M.A. Atkinson, and D.A. Schatz, Autologous umbilical cord blood infusion followed by oral docosahexaenoic acid and vitamin D supplementation for C-peptide preservation in children with Type 1 diabetes. Biol Blood Marrow Transplant, 2013. 19(7): p. 1126-9.

162. Giannopoulou, E.Z., R. Puff, A. Beyerlein, I. von Luettichau, H. Boerschmann, D. Schatz, M. Atkinson, M.J. Haller, D. Egger, S. Burdach, and A.-G. Ziegler, Effect of a single autologous cord blood infusion on betacell and immune function in children with new onset type 1 diabetes: a non-randomized, controlled trial. Pediatric Diabetes, 2014. 15(2): p. 100-109.

163. Wang, H.S., S.C. Hung, S.T. Peng, C.C. Huang, H.M. Wei, Y.J. Guo, Y.S. Fu, M.C. Lai, and C.C. Chen, Mesenchymal stem cells in the Wharton's jelly of the human umbilical cord. Stem cells, 2004. 22(7): p. 13301337.

164. Kalaszczynska, I. and K. Ferdyn, Wharton's Jelly Derived Mesenchymal Stem Cells: Future of Regenerative Medicine? Recent Findings and Clinical Significance. BioMed Research International, 2015. 2015: p. 430847.

165. Hu, J., X. Yu, Z. Wang, F. Wang, L. Wang, H. Gao, Y. Chen, W. Zhao, Z. Jia, S. Yan, and Y. Wang, Long term effects of the implantation of WhartonErsquo;s jelly-derived mesenchymal stem cells from the umbilical cord for newly-onset type 1 diabetes mellitus. Endocrine Journal, 2012. advpub.

166. Li, L., J. Lu, S. Shen, X. Jia, and D. Zhu, Wharton's jelly-derived mesenchymal stem cell therapy to improve $\beta$ cell function in patients with type 1 diabetes and ketoacidosis: a single-centre, single-group, open-label, phase 2 trial. The Lancet Diabetes \& Endocrinology, 2016. 4: p. S17.

167. Hong-Wu Wang, P.N., Han-Hua Yang, Li-Chun Xie, Li-Min Lin, Xiu-Lan Lai, Tian-You Wang, Lian Ma, Partially repair damaged Islets of diabetic rat model via insulin-producing cells differentiated from human umbilical cord mesenchymal stem cells infusion. International Journal of Clinical and Experimental Medicine (IJCEM), 2018. 11(5): p. 4520-4529.

168. Tsai, P.-J., H.-S. Wang, G.-J. Lin, S.-C. Chou, T.-H. Chu, W.-T. Chuan, Y.-J. Lu, Y.-J. Weng, C.-H. Su, P.S. Hsieh, H.-K. Sytwu, C.-H. Lin, T.-H. Chen, and J.-F. Shyu, Undifferentiated Wharton's Jelly Mesenchymal Stem Cell Transplantation Induces Insulin-Producing Cell Differentiation and Suppression of T-Cell-Mediated Autoimmunity in Nonobese Diabetic Mice. Cell Transplantation, 2015. 24(8): p. 1555-1570. 
169. Carlsson, P.-O. and M. Svahn, WhartonE\#8217;s jelly derived allogeneic mesenchymal stromal cells for treatment of type 1 diabetes: Study protocol for a double-blinded, randomized, parallel, placebo-controlled trial. Clinical Trials in Degenerative Diseases, 2018. 3(2): p. 32-37.

170. El-Demerdash, R.F., L.N. Hammad, M.M. Kamal, and H.O. El Mesallamy, A comparison of Wharton's jelly and cord blood as a source of mesenchymal stem cells for diabetes cell therapy. Regen Med, 2015. 10(7): p. 841-55.

171. Som, C. and N.K. Venkataramana, Evaluation of efficacy and regenerative potential of Wharton's jelly and bone marrow derived mesenchymal stem cells in diabetic rats. Journal of Pre-Clinical and Clinical Research, 2018. 12(1): p. 30-35.

172. Szabat, M., D.S. Luciani, J.M. Piret, and J.D. Johnson, Maturation of Adult $\beta$-Cells Revealed Using a Pdx1/Insulin Dual-Reporter Lentivirus. Endocrinology, 2009. 150(4): p. 1627-1635.

173. Meier, J.J., J.C. Lin, A.E. Butler, R. Galasso, D.S. Martinez, and P.C. Butler, Direct evidence of attempted beta cell regeneration in an 89-year-old patient with recent-onset type 1 diabetes. Diabetologia, 2006. 49(8): p. 1838-1844.

174. You, W., J. Yang, Y. Liu, W. Wang, L. Zhu, W. Wang, J. Yang, and F. Chen, Fulminant type 1 diabetes mellitus: Two case reports. Medicine, 2019. 98(5): p. e14319-e14319.

175. Hodson, R., Precision medicine. Nature, 2016. 537: p. S49.

176. Zhao, Y., Z. Jiang, T. Zhao, M. Ye, C. Hu, Z. Yin, H. Li, Y. Zhang, Y. Diao, Y. Li, Y. Chen, X. Sun, M.B. Fisk, R. Skidgel, M. Holterman, B. Prabhakar, and T. Mazzone, Reversal of type 1 diabetes via islet beta cell regeneration following immune modulation by cord blood-derived multipotent stem cells. BMC Med, 2012. 10: p. 3 .

177. Al-Anazi, K., B. K, A.-S. A, A. M, A.-S. Z, A. I, and E. A, Cure of Insulin-Dependent Diabetes Mellitus by an Autologous Hematopoietic Stem Cell Transplantation Performed to Control Multiple Myeloma in a Patient with Chronic Renal Failure on Regular Hemodialysis. Journal of Stem Cell Biology and Transplantation, 2017. 1.

178. Rehan, M., Epigenetics and diabetes mellitus. The Egyptian Journal of Internal Medicine, 2016. 28(2): p. 3951.

179. Sun, L.L., B.G. Jiang, W.T. Li, J.J. Zou, Y.Q. Shi, and Z.M. Liu, MicroRNA-15a positively regulates insulin synthesis by inhibiting uncoupling protein-2 expression. Diabetes Res Clin Pract, 2011. 91(1): p. 94-100.

180. Chakravarthy, H., X. Gu, M. Enge, X. Dai, Y. Wang, N. Damond, C. Downie, K. Liu, J. Wang, Y. Xing, S. Chera, F. Thorel, S. Quake, J. Oberholzer, P.E. MacDonald, P.L. Herrera, and S.K. Kim, Converting Adult Pancreatic Islet alpha Cells into beta Cells by Targeting Both Dnmt1 and Arx. Cell Metab, 2017. 25(3): p. 622-634.

181. Fontcuberta-PiSunyer, M., S. Cervantes, E. Miquel, S. Mora-Castilla, L.C. Laurent, A. Raya, R. Gomis, and R. Gasa, Modulation of the endocrine transcriptional program by targeting histone modifiers of the H3K27me3 mark. Biochim Biophys Acta Gene Regul Mech, 2018. 1861(5): p. 473-480.

182. Bart O Roep Prof, D.C.S.W.B.a.M.P.P., Antigen-based immune modulation therapy for type 1 diabetes: the era of precision medicine. Lancet Diabetes \& Endocrinology, 2019. 7(1): p. 65-74.

183. Beger, R.D., W. Dunn, M.A. Schmidt, S.S. Gross, J.A. Kirwan, M. Cascante, L. Brennan, D.S. Wishart, M. Oresic, T. Hankemeier, D.I. Broadhurst, A.N. Lane, K. Suhre, G. Kastenmüller, S.J. Sumner, I. Thiele, O. Fiehn, R. Kaddurah-Daouk, M. for "Precision, and I. Pharmacometabolomics Task Group"Metabolomics Society, Metabolomics enables precision medicine: "A White Paper, Community Perspective". Metabolomics, 2016. 12(9): p. 149. 
184. Cooper-Dehoff, R.M., W. Hou, L. Weng, R.A. Baillie, A.L. Beitelshees, Y. Gong, M.H. Shahin, S.T. Turner, A. Chapman, J.G. Gums, S.H. Boyle, H. Zhu, W.R. Wikoff, E. Boerwinkle, O. Fiehn, R.F. Frye, R. Kaddurah-Daouk, and J.A. Johnson, Is diabetes mellitus-linked amino acid signature associated with betablocker-induced impaired fasting glucose? Circ Cardiovasc Genet, 2014. 7(2): p. 199-205.

185. Jobin, C., Precision medicine using microbiota. Science, 2018. 359(6371): p. 32-34. 